Fernando Hagihara Borges

\title{
O MEIO AMBIENTE E A ORGANIZAÇÃO: UM ESTUDO DE CASO BASEADO NO POSICIONAMENTO DE UMA EMPRESA FRENTE A UMA NOVA PERSPECTIVA AMBIENTAL
}

Dissertação apresentada à Escola de Engenharia de São Carlos da Universidade de São Paulo, como requisito para a obtenção do Título de Mestre em Engenharia de Produção.

Orientador: Prof. Dr. Wilson Kendy Tachibana

São Carlos

2007 
Fernando Hagihara Borges

\section{O MEIO AMBIENTE E A ORGANIZAÇÃO: UM ESTUDO DE CASO BASEADO NO POSICIONAMENTO DE UMA EMPRESA FRENTE A UMA NOVA PERSPECTIVA AMBIENTAL}

Dissertação apresentada à Escola de Engenharia de São Carlos da Universidade de São Paulo, como requisito para a obtenção do Título de Mestre em Engenharia de Produção.

Orientador: Prof. Dr. Wilson Kendy Tachibana

São Carlos

2007 
AUTORIZO A REPRODUÇÃO E DIVULGAÇÃO TOTAL OU PARCIAL DESTE TRABALHO, POR QUALQUER MEIO CONVENCIONAL OU ELETRONICO, PARA FINS DE ESTUDO E PESQUISA, DESDE QUE CITADA A FONTE.

Ficha catalográfica preparada pela Seção de Tratamento da Informaçăo do Serviço de Biblioteca - EESC/USP

\begin{tabular}{|c|c|}
\hline \multirow[t]{3}{*}{ B732m } & $\begin{array}{l}\text { Borges, Fernando Hagihara } \\
\text { O meio ambiente e a organização: um estudo de caso } \\
\text { baseado no posicionamento de uma empresa frente a uma } \\
\text { nova perspectiva ambiental / Fernando Hagihara Borges ; } \\
\text { orientador Wilson Kendy Tachibana. -- São Carlos, } 2007 .\end{array}$ \\
\hline & $\begin{array}{l}\text { Dissertação (Mestrado-Programa de Pós-Graduação e Área } \\
\text { de Concentração: Engenharia de Produção) - Escola de } \\
\text { Engenharia de São Carlos da Universidade de São Paulo, } \\
2007 \text {. }\end{array}$ \\
\hline & $\begin{array}{l}\text { 1. Gestão ambiental. 2. Desenvolvimento sustentável. } \\
\text { 3. Meio ambiente. 4. Variável ambiental. I. Título. }\end{array}$ \\
\hline
\end{tabular}


Candidato: Bacharel FERNANDO HAGIHARA BORGES

Dissertação defendida e julgada em 16/04/2007 perante a Comissão Julgadora:

Prof. Dr. WILSON KENDY TACHIBANA (Orientador)

(Escola de Engenharia de São Carlos/USP)
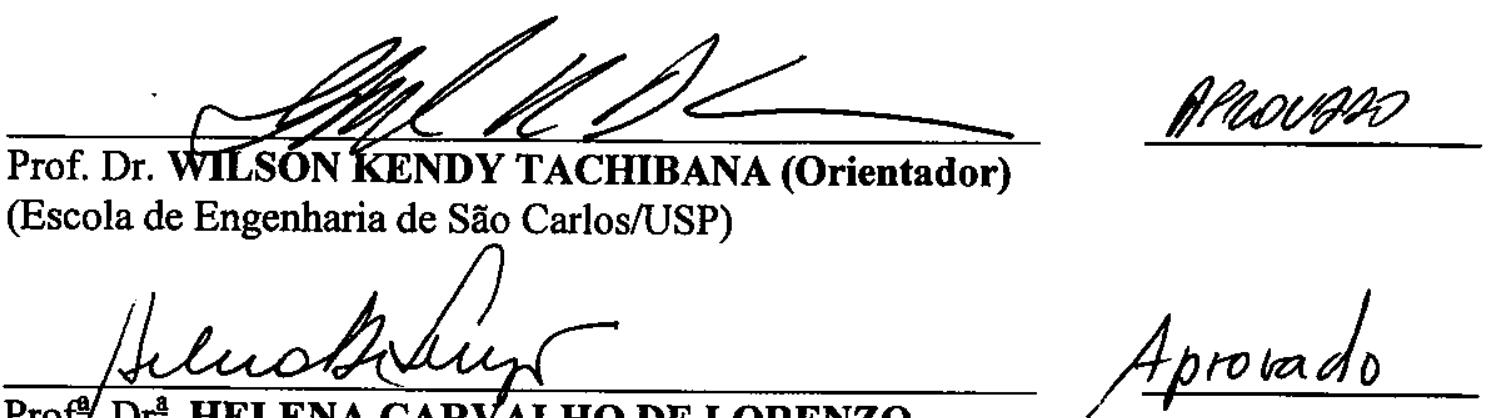

Prof $\%$. Dr ${ }^{\mathrm{a}}$. HELENA CARVALHO DE LORENZO

(Centro Universitárig de Araraquara/UNIARA)

Prof $^{\mathrm{a}}$. Dr ${ }^{\mathrm{a}}$. HAY PÉ TORRES DE OLIVEIRA

APROVA DO

(Universidade Federal de São Carlos/UFSCar)

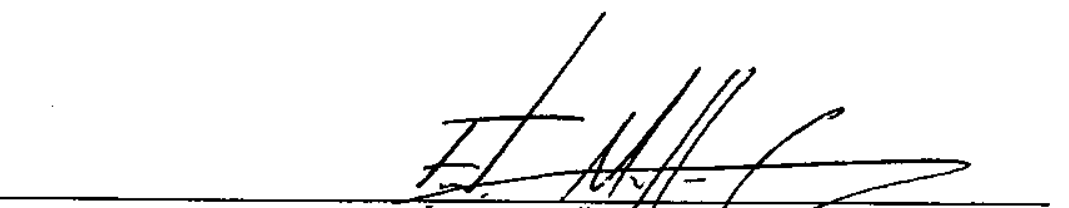

Prof. Associado FÁBIO MÜZLLE GUERRINI

Coordenador do Programa de Pós Graduação em Engenharia de Produção

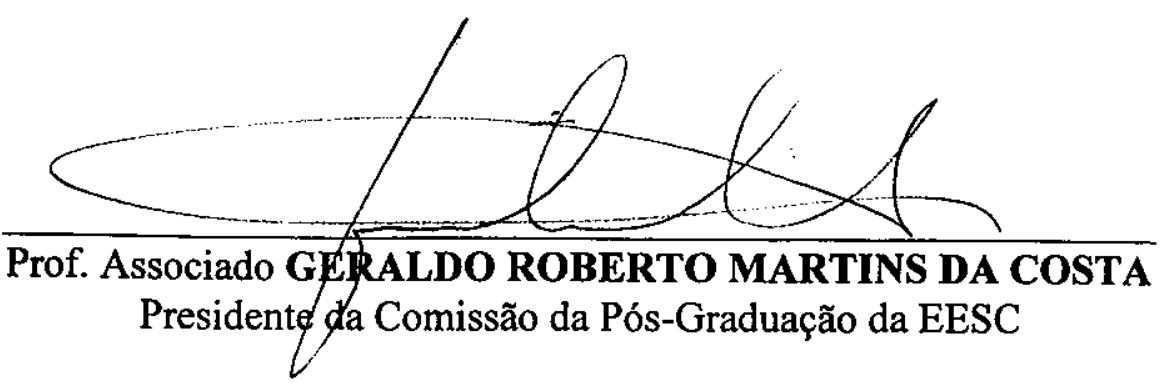




\section{AGRADECIMENTOS}

Não poderia deixar de mencionar aqui todos aqueles que, de alguma forma, contribuíram para que esse trabalho fosse realizado. Meus sinceros agradecimentos e gratidão.

- Ao meu orientador, Prof. Dr. Wilson Kendy Tachibana, por toda paciência, sabedoria e confiança.

- Aos professores Dr. Fernando César Almada dos Santos, Dra. Haydèe Torres de Oliveira, Dr. Edmundo Escrivão Filho.

- Ao Secretário da Seção de Pós-Graduação do Departamento de Engenharia de Produção, José Luiz Donizetti Chiaretto.

- Ao profissional Durval do Santos pela disponibilidade

- Aos professores e amigos do mestrado que me acompanharam.

- Ao Professor Paulo Zucolotto e ao Centro de Economia e Administração da Pontifícia Universidade Católica de Campinas.

- À Universidade de São Paulo pela oportunidade de desfrutar de sua exemplar infra-estrutura.

- Aos amigos Alan Quilimarte, Alan Rodrigo Bicalho, Allan Gloe Dizioli, José Roberto Ribeiro, Caio Poli, Fernando da Silva Pereira e Thiago Daniel Tavares Ribeiro pelo apoio e companheirismo.

- Aos Caríssimos colegas de trabalho e de viagens.

- Aos meus Pais e Familiares pelo apoio incondicional.

- À Érika Bergamasco Guesse por sua dedicação, amor e carinho durante todos estes anos de luta. 


\section{RESUMO}

O presente trabalho tem por objetivo as motivações que tencionam as organizações empresariais a adotar práticas de gestão ambiental, bem como o modo de internalizaçao dessas práticas. Para a realização de tal intento, o projeto foi dividido em três partes principais. Na primeira parte, levou-se a cabo uma revisão da literatura pertinente, com a apresentação de um panorama histórico acerca do tratamento das questões ambientais, a apreciação dos conceitos e abordagens teóricas que a gestão ambiental empresarial vem assumindo e, o tratamento dado pela teoria econômica sobre o assunto. Na segunda parte, empreendeu-se um estudo de caso de uma organização com postura ambiental diferenciada, no qual procurou-se elucidar os aspectos relativos aos modos e motivações que levaram a instituição a adotar tal comportamento. As informações, obtidas durante o processo de coleta de dados, salientam que, apesar do posicionamento ambiental adequado da empresa, a internalizaçao da variável ambiental é principalmente motivada por fatores econômicos-financeiros. Num primeiro instante, a empresa resguardase da aplicação dos dispositivos legais vigentes; em uma etapa posterior, com a visualização de oportunidades de retornos financeiros decorrentes dos ganhos em eficiência operacional como também da melhoria da imagem institucional, a empresa passa a ser mais atuante.

Palavras-chave: gestão ambiental; desenvolvimento sustentável; meio ambiente; variável ambiental. 


\section{SUMÁRIO}

LISTA DE FIGURAS

LISTA DE QUADROS 2

1. INTRODUÇÃO 3

1.1 A QUESTÃO AMBIENTAL E AS ORGANIZAÇÕES 3

1.2 UMA NOVA REALIDADE E A POSTURA ORGANIZACIONAL 4

1.3 JUSTIFICATIVA 6

1.4 OBJETIVO 6

1.5 PROBLEMA DE PESQUISA

1.6 HIPÓTESE

1.7 PROCEDIMENTOS METODOLÓGICOS 8

$\begin{array}{ll}1.8 \text { DELIMITAÇÕES DO ESTUDO } & 10\end{array}$

1.9 ESTRUTURA DO TRABALHO

1.10 RESULTADOS ESPERADOS

2. A RELAÇÃO ENTRE HOMEM E MEIO AMBIENTE: A PREOCUPAÇÃO AMBIENTAL AO LONGO DO TEMPO

2.1 OS PRIMÓRDIOS DA PREOCUPAÇÃO AMBIENTAL 13

2.2 O DESPERTAR INTERNACIONAL PARA AS QUESTÕES AMBIENTAIS 16

2.2.1 O CLUBE DE ROMA E OS LIMITES DO CRESCIMENTO 17

2.2.2 A CONFERÊNCIA DE ESTOCOLMO

2.2.3 O PERÍODO PÓS-ESTOCOLMO 20

2.2.4 A FASE ATUAL: RIO-92 - UM MARCO INICIAL 21

2.3 OS REFLEXOS DA PREOCUPAÇÃO AMBIENTALISTA NO AMBIENTE DE NEGÓCIOS 24

3. A VARIÁVEL AMBIENTAL NO AMBIENTE EMPRESARIAL 27

3.1 A GESTÃO AMBIENTAL E SUAS PERSPECTIVAS 29

3.1.1 OS INDUTORES DA GESTÃO AMBIENTAL 29

3.2 A GESTÃO AMBIENTAL NA EMPRESA 32

3.2.1 SISTEMAS DE GESTÃO AMBIENTAL 36

3.2.2 DIFERENTES ABORDAGENS PARA A GESTÃO AMBIENTAL EMPRESARIAL 37

3.3 A VARIÁVEL AMBIENTAL E AS QUESTÕES COMPETITIVAS 42

3.3.1 CONCEPÇÕES DIFERENTES

4. A ECONOMIA E O DESENVOLVIMENTO SUSTENTÁVEL 48

4.1 O CAPITAL NATURAL À LUZ DA ECONOMIA 49

4.2 A SUSTENTABILIDADE FRACA

4.3 A SUSTENTABILIDADE FORTE

5. ESTUDO DE CASO 63

5.1 CRITÉRIOS PARA A ESCOLHA DA ORGANIZAÇÃO: OBJETO DO ESTUDO DE CASO 63

5.2 O PROCESSO DE COLETA DE DADOS E INFORMAÇÕES 
5.4 APRESENTAÇÃO DOS DADOS E INFORMAÇÕES

5.4.1 A VARIÁVEL AMBIENTAL E A ORGANIZAÇÃO

5.4.2 ORIENTAÇÕES ESPECÍFICAS

5.5 ANÁLISE DAS INFORMAÇÕES

6. CONSIDERAÇÕES FINAIS

REFERÊNCIAS 


\section{LISTA DE FIGURAS}

Figura 1 - quadro evolutivo das questões ambientais .................................24

Figura 2 - Os indutores da gestão ambiental empresarial............................ 33

Figura 3 - Fatores e ferramentas de gestão ambiental ...............................44

Figura 4 - As diferentes formas de capital............................................. 51

Figura 5 - O sistema econômico pela sustentabilidade fraca .........................53

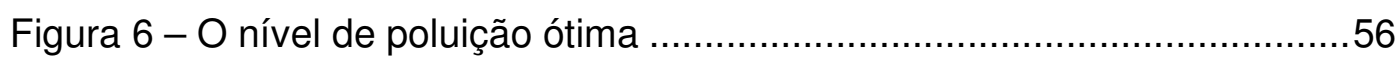

Figura 7 - O sistema econômico pela sustentabilidade forte .........................58 


\section{LISTA DE QUADROS}

Quadro 1 - Instrumentos de Política Ambiental ....................................... 30

Quadro 2 - Diferentes abordagens da gestão ambiental empresarial ...............37

Quardo 3 - A gestão dos residuos........................................................ 68

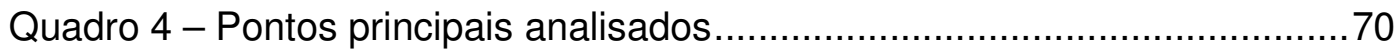




\section{INTRODUÇÃO}

\subsection{A questão ambiental e as organizações}

A busca pela harmonia entre o homem e o meio ambiente vem sendo cada vez mais debatida nas últimas décadas como fator essencial para a sobrevivência, não somente da espécie humana, como de todo o planeta.

A preocupação com o estado do meio ambiente, segundo Barbieri (2004), não é recente, mas, de certa forma, foi nas últimas três décadas do século $X X$ que ela entrou definitivamente na agenda dos governos de muitos países e de diversos segmentos da sociedade civil organizada.

Alguns autores, como Donaire (1999), Kinlaw (1997) e Porter (1999), observam que uma população cada vez mais consciente e ativa com relação à questão ambiental vem exigindo, por parte dos governantes e das empresas, medidas que possam vir a contribuir para o desenvolvimento sustentável, ou seja, deve haver um equilíbrio entre o consumo de recursos disponíveis e a garantia de disponibilidade desses para gerações futuras.

Desta forma, observa-se que o meio ambiente vem sendo reconhecido ao longo do tempo, não apenas como uma fonte de recursos, mas como um bem a ser preservado pela sociedade.

Esta nova perspectiva está ganhando força ao redor do mundo e conquistando consumidores mais interessados por produtos de maior apelo ambiental, principalmente, nos países Europeus (JUNQUEIRA, 2002).

Paralelamente, legislações ambientais específicas, que objetivam controlar a instalação de novas indústrias e estabelecer exigências para as emissões das indústrias existentes, contribuem para que as empresas adotem processos produtivos mais limpos.

Os problemas ambientais, por mais variados que sejam, decorrem do uso do meio ambiente como fonte de recursos para a produção da subsistência humana e como recipiente de resíduos da produção e consumo, sendo que tais 
problemas são agravados pelo modo como os humanos concebem a sua relação com a natureza. Qualquer solução efetiva para os problemas ambientais terá necessariamente que envolver as empresas, pois são essas que produzem e comercializam a maioria dos bens e serviços disponíveis à sociedade (BARBIERI, 2004).

Ao ser aplicado o conceito de desenvolvimento sustentável às empresas, Kinlaw (1997) destaca que esse pode ser substituído pelo conceito de desempenho sustentável: a evolução das empresas para sistemas de produção de riqueza que sejam completamente compatíveis com os ecossistemas naturais que geram e preservam a vida. $\mathrm{O}$ desempenho sustentável possui duas características fundamentais que o distingue do desenvolvimento sustentável: lucro de desempenho.

Junqueira (2002) observa que a nova realidade vivenciada pelas organizações contribui para que os gestores incluam a variável ambiental como um dos fatores a serem analisados. O objetivo é alcançar uma harmonia entre o retorno esperado de um investimento e o consumo de recursos naturais.

\subsection{Uma nova realidade e a postura organizacional}

Como apresentado anteriormente, uma nova perspectiva acerca da questão ambiental está se consolidando, ganhando ruas, auditórios, a imprensa, e fazendo parte do vocabulário de políticos, empresários, administradores, líderes sindicais, dirigentes de ONG's e cidadãos de um modo geral. Por outro lado, para a maioria das empresas, essa preocupação ainda não se transformou em práticas administrativas e operacionais efetivas, pois se tal já estivesse ocorrendo, o acúmulo de problemas ambientais certamente não se daria de forma tão intensa.

As mudanças no ambiente das organizações, em um primeiro momento, restringiu-se ao cumprimento legal e a ações corretivas (Junqueira, 2002). Alguns autores, como Valle (2000), argumentam que a proteção ambiental, antes das décadas de 70 e 80, era vista por um ângulo defensivo, estimulando apenas soluções corretivas baseadas no estrito cumprimento da legislação. 
Com a criação da maioria dos órgãos ambientais governamentais ocorrendo após a Conferência das Nações Unidas sobre o Meio Ambiente Humano, realizada em Estocolmo no ano de 1972, a legislação ambiental começa a crescer vertiginosamente, e a contribuir com o vínculo das questões ambientais às do desenvolvimento (BARBIERI, 2004).

Tal evento representou um marco com relação ao tratamento das questões ambientais, que, até então, estavam sendo tratadas de forma fragmentada. A partir disso, a percepção dos empresários sobre soluções corretivas, com relação ao cumprimento estrito das leis, passa a tomar novas formas, e a ser considerada como uma necessidade, pois reduz o desperdício de matérias-primas e assegura uma boa imagem para a empresa (Valle, 2000).

A mudança de postura por parte dos empresários frente às questões ambientais é destacada por Hansen e Mowen (2001) como sendo decorrente do aumento significativo da regulamentação ambiental e da percepção de que é menos oneroso prevenir a poluição do que remediá-la.

Outro fator determinante para tal postura é a possibilidade de conquista de novos consumidores (mais engajados aos apelos ambientais), dispostos a pagar mais por produtos menos nocivos ao meio ambiente.

Segundo Porter (1999), o desempenho ambiental satisfatório, antes considerado pelos gestores como uma variável que não agregava valor ao processo produtivo e, portanto, era fator que ia de encontro ao desenvolvimento econômico e à lucratividade das empresas, passou a ser visto como uma vantagem competitiva, pois muito embora possa vir a ter o seu resultado reduzido no curto prazo, tal resultado é recuperado pela melhoria do desempenho no médio e longo prazo.

A poluição é uma forma de desperdício e um indício de ineficiência dos processos produtivos, segundo Valle (2000). Quando uma empresa provoca algum tipo de dano ambiental, normalmente o está fazendo por meio de rendimentos insatisfatórios em seu processo produtivo. Desta forma vê parte de seus lucros se escoar através de recursos que não foram devidamente utilizados no processo produtivo. 


\subsection{Justificativa}

Qualquer solução efetiva para os problemas ambientais irão inevitavelmente envolver as empresas, que ocupam posição central nessa questão.

O trabalho torna-se relevante à medida que os recursos naturais apresentam baixa resiliência quanto a sua utilização, podendo comprometer a capacidade de carga do planeta. Muito embora várias questões tenham sido contornadas pela tecnologia, a mitigação dos problemas relacionados à degradação ambiental está distante de um ponto final. A inserção da empresa no meio ambiente precisa ser discutida sob esta visão, justificando o presente trabalho.

\subsection{Objetivo}

Como apresentado anteriormente, a busca da harmonia entre o homem e o meio ambiente tem resultado em debates intensos nas últimas décadas.

O reconhecimento de que o meio ambiente não é apenas uma fonte de recursos, mas sim um "patrimônio" que a sociedade como um todo tem de preservar, começa a mudar a perspectiva acerca das medidas a serem tomadas com relação à temática ambiental.

Sendo as empresas as maiores usuárias dos recursos disponíveis na natureza, produzindo e comercializando produtos ao redor do mundo, terão de, necessariamente, estar no cerne da discussão acerca de soluções ambientais.

A partir da Conferência de Estocolmo, em 1972, o conceito de desenvolvimento sustentável torna-se cada vez mais visível à sociedade civil; prova disso é a criação de diversas entidades governamentais e nãogovernamentais (cuja finalidade é de fiscalizar a ação dos agentes econômicos), bem como o crescimento do aparato jurídico específico ao tema.

Desta forma, o presente trabalho tem por propósito analisar a inserção da organização empresarial no meio ambiente, buscando identificar os fatores 
que provocam a internalização das questões ambientais em seus objetivos de negócio.

Como objetivos específicos deste trabalho têm-se:

- Realizar um levantamento bibliográfico acerca da evolução da preocupação ambiental e seus impactos no ambiente dos negócios;

- Buscar na literatura as definições e as perspectivas teóricas do conceito de gestão ambiental empresarial;

- Visualizar as vertentes teóricas que permeiam a integração da variável ambiental pelas empresas;

- Revisar a literatura pertinente com o intuito de identificar o tratamento do conceito de desenvolvimento sustentável pela teoria econômica e;

- Checar o enquadramento prático da empresa frente às perspectivas teóricas apresentadas.

\subsection{Problema de pesquisa}

Segundo Gil (1999), problema é, na acepção científica, qualquer questão não resolvida e que é objeto de discussão, em qualquer domínio do conhecimento. Um problema é testável cientificamente quando envolve variáveis que podem ser observadas ou manipuladas.

Com base na discussão das outras seções, é possível constatar que a adesão às questões ambientais nas decisões organizacionais pode contribuir para melhoria nos resultados, a partir da otimização da utilização dos recursos e da melhoria da imagem da organização, com a possibilidade de atração de novos consumidores e a manutenção dos atuais. Somado a isto, tem-se também a idéia de que torna-se menos oneroso para a organização a prevenção de danos ambientais do que a simples aderência à soluções paleativas, pois com o aumento do rigor das legislações específicas e o aumento da conscientização por parte dos consumidores, tais medidas podem se tornar prejudiciais às empresas. 
Há de se considerar, porém, a visão tradicional da empresa em relação aos resultados. A idéia subjacente é a de maximização dos lucros e, para tanto, as questões ambientais, de uma forma geral, deverão estar sob este enfoque.

A questão proposta para o presente estudo é a de investigar como uma organização empresarial integra (ou internaliza) as questões ambientais frente a uma nova perspectiva de meio ambiente, destacando quais medidas/procedimentos estão sendo tomadas.

A partir disso, a questão de pesquisa pode ser formulada da seguinte forma:

Como e por que a empresa internaliza a variável ambiental em seus processos de negócio?

\subsection{Hipótese}

Para a construção da hipótese, leva-se em conta que a mesma é uma proposição que se forma e que será aceita ou rejeitada somente depois de devidamente testada. Seu papel fundamental é sugerir explicações para os fatos (Gil, 1999).

A hipótese de trabalho formulada se apresenta da seguinte forma:

Como as empresas normalmente focam a maximização dos lucros e/ou a maximização da riqueza dos proprietários, as questões relativas ao meio ambiente só serão incorporadas quando apresentarem perspectivas de vantagens econômicas, de restrições jurídicas e de opções sociais.

\subsection{Procedimentos metodológicos}

Primeiramente a definição de um plano geral faz-se necessária, elaborado com base na literatura pertinente ao assunto, reunindo informações que progressivamente foram ampliando as condições necessárias à tomada de decisão das estratégias de pesquisa, permitindo delinear contornos mais definidos em relação aos propósitos do trabalho e aos encaminhamentos a serem priorizados. 
À medida que as tarefas primárias de uma pesquisa são concretizadas, o trabalho de investigação assume o caráter de um sistema coordenado e coerente de conceitos e proposições.

A presente pesquisa é positivista, à medida que só considera o empírico, trata com variáveis verificáveis e focaliza um fenômeno visível. Tem o propósito de exploração para evidenciar a existência de um fenômeno e, de descrição para definir e diferenciar o objeto de estudo (Dane, 1990), dado que o embasamento teórico sobre gestão ambiental é recente e não se consolida como uma teoria formulada.

Este estudo obedece aos três princípios da ciência: princípio das evidências verificáveis, princípio da parcimônia, princípio da verificação experimental.

Segundo Gil (1999), o delineamento da pesquisa refere-se ao planejamento da mesma em sua dimensão mais ampla, envolvendo tanto a sua diagramação quanto a previsão de análise e interpretação dos dados. Constitui a etapa em que o pesquisador passa a considerar a aplicação dos métodos discretos, ou seja, daqueles que proporcionam os meios teóricos para a investigação.

Os procedimentos metodológicos do presente trabalho dividem-se em duas fases. Na primeira fase, será efetuada uma pesquisa bibliográfica, na qual buscar-se-á a utilização dos principais livros-técnicos, dissertações, teses, artigos científicos, entre outras fontes, com o objetivo de efetuar um levantamento das principais questões referentes ao tema de pesquisa.

Em seguida, será proposto um estudo de caso envolvendo uma empresa do setor químico, de grande porte, visando evidenciar o posicionamento dessa, frente ao tratamento das questões de preservação do meio ambiente.

Para Gil (1999), o estudo de caso é caracterizado pelo estudo profundo e exaustivo de um ou de poucos objetos, de maneira a permitir o seu conhecimento amplo e detalhado.

Yin (2001) destaca que cada estratégia apresenta vantagens e desvantagens próprias, dependendo basicamente de três condições: tipo de questão de pesquisa; controle que o pesquisador possui sobre os aspectos 
comportamentais efetivos e o foco em fenômenos históricos em oposição a fenômenos contemporâneos.

Ainda segundo Yin (2001), os estudos de caso representam a estratégia preferida quando se colocam questões do tipo "como" e "por quê", quando o pesquisador tem pouco controle sobre os eventos e quando o foco se encontra em fenômenos contemporâneos inseridos em algum contexto da vida real.

O estudo de caso permite uma investigação para se preservar as características holísticas e significativas dos eventos da vida real - tais como ciclos de vida individuais, processos organizacionais e administrativos, mudanças ocorridas em regiões urbanas, relações internacionais e maturação de alguns setores.

A presente pesquisa será realizada com o propósito de efetuar o diagnóstico detalhado do posicionamento da empresa abordada, acerca das questões ambientais. Neste sentido, o foco de interesse é a definição de sua singularidade, podendo-se posteriormente fazer comparações, verificando semelhanças e contrastes com outras experiências.

Pretende-se, com este método, seguir uma seqüência composta por três fases: exploratória, coleta de dados e a análise das informações obtidas. A coleta de dados se dará através da formulação de entrevistas a serem aplicadas aos responsáveis pelo tratamento das questões ambientais da empresa; análise de materiais institucionais de divulgação tais como folhetos informativos; apostilas; vídeos, entre outros, e observação direta.

A escolha desta empresa para o estudo de caso se dá pela sua clara e diferenciada preocupação com a preservação do meio ambiente, encaixandose dentro dos três fundamentos lógicos apresentados por Yin (2001) para projetos de caso único, representando um caso raro (diferenciado) ou extremo.

\subsection{Delimitações do estudo}

A globalização dos problemas ambientais é um fato incontestável e as empresas estão, desde a sua origem, no centro desse processo. 
O estudo não tem por objetivo uma generalização quanto ao posicionamento das organizações frente às questões ambientais. O que se pretende é apresentar as características intrínsecas à empresa estudada, podendo gerar contribuições para a própria empresa quanto para outras empresas e pesquisadores em gestão ambiental.

\subsection{Estrutura do trabalho}

No primeiro capítulo da revisão de literatura, discutir-se-á a relação Homem e Meio Ambiente, a partir de um quadro evolutivo das preocupações ambientais por parte da sociedade civil. Toma-se como marco referencial, a Conferência de Estocolmo (I CNUMAD) realizada no ano de 1972.

No segundo capítulo, serão discutidas as perspectivas teóricas relativas à inserção da variável ambiental no ambiente empresarial; bem como o tratamento conceitual de gestão ambiental empresarial e seu relacionamento com questões relacionadas à estratégia em competitividade.

O terceiro capítulo abordará os aspectos relativos ao tratamento das questões ambientais, mais especificamente o conceito de sustentabilidade pela Teoria Econômica, destacando as principais correntes e suas respectivas considerações.

O estudo de caso será apresentado no quarto capítulo, evidenciando a coleta, o tratamento e a análise dos dados. Realizada esta etapa, no quinto e último capítulo serão apresentadas as considerações finais do trabalho.

\subsection{Resultados esperados}

Com o presente trabalho de pesquisa, pretende-se chegar a algumas conclusões que demonstrem que o processo de adesão ao tratamento das questões ambientais pela empresa ocorre num primeiro instante pelas motivações citadas na hipótese do trabalho (vantagens econômicas, restrições jurídicas e/ou opções sociais) e, que a partir de então, passam ser desenvolvidas ações que se encaixem num contexto de pró-atividade empresarial. 
Espera-se também que a pesquisa possibilite a formulação de novas questões como também novas pesquisas, dando continuidade à linha adotada. 


\section{A relação entre homem e meio ambiente: a preocupação ambiental ao longo do tempo}

Este capítulo descreve a relação Homem e Meio ambiente partindo do foco das preocupações ambientais abordadas nos principais eventos, acordos e discussões acerca do tema ao redor do mundo. Como marcos iniciais, utilizar-se-ão a publicação do relatório de pesquisa realizado pelo Clube de Roma em meados dos anos 70 intitulado "Limites do Crescimento", como também a Conferência de Estocolmo realizada no ano de 1972.

[...] ambientalismo é, ao mesmo tempo, uma utopia, uma ética e uma cultura. Ambientalismo supõe tanto examinar os chamados comportamentos destrutivos, da predatória sociedade industrial e pós-industrial, como também instalar uma concepção preservadora e preventiva que repense os usos e costumes da modernidade e seu impacto no futuro da vida humana e da natureza (SPOSATI, 2002, p.15) .

\subsection{Os primórdios da preocupação ambiental}

O impacto das atividades humanas sobre o meio ambiente não é um fenômeno recente. Os primeiros humanos eram caçadores nômades e retiravam da natureza somente o necessário para o seu sustento. Este modo de vida permitiu a ocupação de todo o mundo, por parte do homem.

A primeira grande mudança no modo de vida do homem, até então marcado principalmente pelas atividades de caça e pesca para a subsistência, foi o desenvolvimento da agricultura. Sua expansão, juntamente com o aumento populacional, contribuiu para os primeiros desmatamentos, não somente para a obtenção de terras cultiváveis, como também para a utilização de árvores como combustível (JUNQUEIRA, 2002). Romeiro (2004) destaca ainda que, com a invenção da agricultura, a humanidade deu um passo 
decisivo na diferenciação de seu modo de inserção na natureza em relação àquele das demais espécies de animais.

Outra grande mudança ocorreu com o desenvolvimento da manufatura (entre os séculos XVI e XVII), implicando em mudanças radicais sob todos os aspectos nas relações sociais e de trabalho (MORANDI e GIL, 2000). Esse período histórico, que precedeu a Revolução Industrial, caracterizou-se pelo surgimento de uma forma de vida muito dependente de energia não-renovável.

A Revolução Industrial do século XVIII pode ser entendida como uma primeira grande arrumação espacial interligando as regiões do mundo. Alguns economistas chegam a tratar este período como "a primeira economia interligada e organizada em escala mundial". Romeiro (2004) pontua o fato de que a Revolução Industrial aumentou contínua e vertiginosamente a capacidade da humanidade em intervir na natureza.

Barbieri (2004) observa que o aumento da escala produtiva tem sido um importante fator que estimula a exploração dos recursos naturais, elevando a quantidade de resíduos gerados. Esse autor ainda destaca que, a partir da Revolução Industrial, surge uma diversidade de substâncias e materiais que não existiam na natureza. A maneira como a produção e o consumo estão sendo conduzidos desde então exige recursos e gera resíduos, ambos em quantidades vultosas, que estão ameaçando a capacidade de suporte/assimilação do próprio planeta.

O desenvolvimento tecnológico e o conseqüente aumento da produtividade na Era da Revolução Industrial provocaram uma melhora substancial na qualidade de vida material. Entretanto, já na primeira metade do século $X X$, foi possível constatar novas provas do eventual dano em grande escala que as novas tecnologias poderiam causar ao meio ambiente. Se por um lado os sistemas industriais alcançaram apogeus de sucesso, o capital natural, do qual depende a prosperidade econômica da civilização, declinou rapidamente, sendo que o índice de perdas cresceu na mesma proporção dos ganhos em termos de bem-estar material (HAWKEN, LOVINS e LOVINS, 1999). 
Hawken, Lovins e Lovins (1999) afirmam que, durante este período, a humanidade presenciou uma degradação ambiental sem precedentes, com o povoamento das cidades e a mecanização da produção agrícola. Já Barbieri (2004) ressalta que o nível de produção que o ambiente pode sustentar tem gerado polêmicas acirradas desde muito tempo e que os posicionamentos e as propostas relativas a essa questão variam dentro de um continnum que se estende do otimismo ao pessimismo extremados. Romeiro (2004) argumenta que, além dos desequilíbrios ambientais gerados pela maior capacidade de intervenção humana na natureza, a Revolução Industrial, baseada no uso intensivo de grandes reservas de combustíveis fósseis, abriu caminho para uma expansão inédita da escala das atividades humanas, que exerceu forte pressão sobre a base de recursos naturais do planeta, culminando no questionamento sobre a capacidade de carga do planeta (carrying capacity).

Neste contexto, surge a teoria de Malthus, considerado o primeiro economista a prever os limites de crescimento causados pela escassez de recursos naturais. Malthus expressou a sua teoria dos limites ambientais através de restrições de suprimento de terras férteis de boa qualidade e dos resultantes retornos decrescentes na produção agrícola (MEBRATU, 1998).

O adjetivo "malthusiano" é utilizado para indicar pessoas pessimistas quanto ao futuro devido ao descompasso entre recursos e necessidades e à dificuldade de conter o crescimento populacional (BARBIERI, 2004). Na realidade, segundo Mebratu (1998) e Barbieri (2004), a tecnologia foi fator preponderante para não se verificar o pessimismo de Malthus, a não ser em casos isolados.

Desta forma, num outro extremo, posicionam-se aqueles que demonstram um otimismo exagerado em relação aos recursos necessários à vida humana. A premissa básica é que, mediante qualquer problema de escassez no presente ou no futuro próximo, sempre haverá a possibilidade de aumento de produtividade, substituição de insumos e melhoria de processos produtivos através de pesquisa e desenvolvimento tecnológico. Tal postura é denominada "cornucopiana", em alusão à cornucópia, figura mitológica que simboliza fortuna e abundância eternas (BARBIERI, 2004). 
Este posicionamento é observado na obra de Adam Smith, $A$ riqueza das nações, quando este autor ressalta que, independentemente do solo, clima ou extensão territorial de uma determinada nação, a abundância ou escassez de bens que esta vai dispor dependerá de duas circunstâncias: da habilidade, destreza e do bom senso com que o trabalho é executado e; da proporção entre os que executam o trabalho útil e os que não executam. De acordo com este economista, sempre haverá demanda por alimentos e esses sempre irão demandar trabalho e sempre haverá alguém disposto a produzi-los, de modo que a terra sempre vai produzir uma quantidade de alimentos mais que suficiente para remunerar o trabalho e repor o capital. Para Barbieri (2004), talvez em decorrência desse tipo de argumento, o fator Terra tem sido omitido em muitos textos econômicos no quais apenas o trabalho e o capital foram considerados fatores de produção.

\subsection{O despertar internacional para as questões ambientais}

Andrade, Tachizawa e Carvalho (2000) observam que a internacionalização do movimento ambientalista ocorreu definitivamente no século XX com a Conferência Científica da ONU sobre a Conservação e Utilização de Recursos, em 1949, e com a Conferência sobre Biosfera, realizada em Paris, em 1968. Porém, os grandes marcos do despertar de uma consciência ecológica mundial foram: a publicação do Relatório Limites do Crescimento, elaborado pelo Clube de Roma e a Conferência de Estocolmo, em 1972 (I CNUMAD), que teve por objetivo conscientizar os países sobre a importância da conservação ambiental como fator fundamental para a manutenção da espécie humana. A palavra-chave em Estocolmo foi poluição.

Mebratu (1998) destaca que o debate ambiental contemporâneo assume, predominantemente, que a preocupação ambiental está ligada ao problema da poluição industrial.

O conceito de desenvolvimento sustentável surgiu com a publicação do relatório "Nosso Futuro Comum" em 1987, e ganhou, ao longo dos anos, crescente importância nas políticas nacionais, internacionais e corporativas. 
Contudo, antes de se discutir o conceito de desenvolvimento sustentável, necessita-se fazer uma revisão histórica e conceitual dos precursores deste, que pode ser dividida em três períodos principais:

1- I Conferência das Nações Unidas Para o Meio Ambiente Humano, em Estocolmo e a publicação do Relatório Limites do Crescimento, elaborado pelo Clube de Roma.

2 - Relatório Nosso Futuro Comum, publicado pela Comissão Mundial para o Desenvolvimento e Meio Ambiente (criada pela ONU), em 1987.

3 - Conferência das Nações Unidas para o Meio Ambiente e Desenvolvimento, realizada no Rio de Janeiro, em 1992, e o Protocolo de Kyoto.

\subsubsection{O Clube de Roma e os Limites do Crescimento}

A publicação do Relatório Limites do Crescimento foi a primeira abordagem em termos globais dos problemas associados à degradação ambiental.

No ano de 1968, um grupo de trinta pessoas de países diferentes, composto por educadores, cientistas, economistas, humanistas, industriais e funcionários públicos de nível nacional e internacional, reuniram-se com o intuito de discutir os dilemas que a humanidade estava vivenciando e todos os mais que poderiam surgir (MEADOWS et al. 1972, p. 3).

Deste encontro surge o "Clube de Roma", uma organização informal que tinha por objetivo promover o entendimento dos componentes variados, mas interdependentes: econômicos, políticos, naturais e sociais, que formam o sistema global, como também chamar a atenção dos tomadores de decisões de alto alcance e do público mundial. Meadows et al. (1972) destaca que o objetivo do projeto é examinar o complexo de problemas que afligem os povos de todas as nações tais como: pobreza, degradação ambiental, expansão urbana descontrolada, insegurança de emprego, transtornos econômicos e monetários dentre outros. Os elementos, segundo os autores, aparentemente divergentes, possuem três características essenciais: ocorrem até certo ponto 
em todas as sociedades; contêm elementos técnicos, sociais, econômicos e políticos; e, o fator mais importante: atuam uns sobre os outros.

Os relatórios do Clube de Roma são expressões típicas da visão neomalthusiana que tiveram destaque tanto no meio acadêmico quanto na grande imprensa e contribuíram para divulgar o pessimismo sobre as possibilidades de a Terra sustentar o crescimento econômico (BARBIERI, 2004).

O mais famoso destes relatórios, "Limites do Crescimento", publicado em plena crise do petróleo (início dos anos 1970), sustenta o pessimismo de seus relatores através de simulações realizadas num modelo de sistema mundial.

Meadows et al. (1972) relatam que o modelo mundial fora construído especificamente para investigar cinco grandes tendências de interesse global: o ritmo acelerado de industrialização, o rápido crescimento demográfico, a desnutrição generalizada, o esgotamento dos recursos naturais não-renováveis e a deterioração ambiental. Estas tendências se inter-relacionam de muitos modos, e seu desenvolvimento se mede em décadas ou séculos mais do que em meses ou anos. Com este modelo, os seus formuladores tentaram compreender as causas que motivam estas tendências, suas inter-relações e implicações ao longo do tempo.

O relatório afirma que, caso não haja mudanças significativas nas relações físicas, econômicas e sociais observadas até então, a produção industrial e a população crescerão rapidamente para decrescer depois, no decorrer do próximo século; a produção decrescerá devido à diminuição de recursos e a população, pela elevada taxa de mortalidade devido à diminuição dos alimentos e dos serviços médicos. Os resultados obtidos destacam ainda que, mesmo com a duplicação dos recursos naturais, o colapso populacional não seria impedido, porque o elevado crescimento industrial decorrente da maior oferta de recursos elevaria o nível de poluição para além da capacidade de assimilação do meio ambiente, o que aumentaria a taxa de mortalidade e reduziria a produção de alimentos (BORGES e TACHIBANA, 2005). 
Em todas as simulações apresentadas, sempre haverá crise de abastecimento decorrente do crescimento econômico, mesmo na hipótese de reservas ilimitadas de recursos obtidos com progresso técnico, controle de poluição e de natalidade.

Frey e Camargo (2003) fazem referência ao alerta que o relatório causou em termos mundiais sobre a sustentabilidade das ações humanas vigentes até então. As autoras ainda salientam que a polêmica gerada pelo relatório, alertara as autoridades para a necessidade de diferenciação entre crescimento e desenvolvimento econômico, servindo de subsídio para os debates da Conferência de Estocolmo.

\subsubsection{A Conferência de Estocolmo}

A I Conferência das Nações Unidas para o Meio Ambiente Humano, realizada em Estocolmo no ano de 1972, reconheceu a importância do gerenciamento ambiental e o uso da avaliação ambiental como uma ferramenta de gestão e representou um grande passo para o desenvolvimento do conceito de desenvolvimento sustentável (Mebratu, 1998). O período compreendido entre esta e a conferência ocorrida no Rio, segundo Barbieri (2004), se caracteriza pela busca de uma nova relação entre meio ambiente e desenvolvimento, pois, mesmo sem esta relação estar plenamente consolidada, havia indicações a forma com que o desenvolvimento econômico estava sendo conduzido teria de sofrer alterações (Mebratu, 1998). Como destaca Jacobi (1999), é nesta fase que se difunde a crítica ambientalista ao modo de vida contemporâneo.

Este evento colocou a questão ambiental nas agendas oficiais e nas organizações internacionais, enfocando a necessidade de tomar-se medidas efetivas de controle dos fatores que causam a degradação ambiental (Frey e Camargo, 2003, Jacobi, 1999 e Junqueira, 2002). Barbieri (2004) cita que a conferência foi marcada pelo antagonismo entre dois blocos: os países desenvolvidos, preocupados com a poluição e o esgotamento de recursos estratégicos e os demais países, que defendiam o direito de usarem seus recursos para crescer e assim ter acesso aos padrões de bem-estar alcançados pelas populações dos países ricos. O autor ressalta ainda que 
apesar destas divergências, o encontro conseguiu avanços positivos, dentre eles a aprovação da Declaração sobre o Ambiente Humano, um plano de ação constituído de cento e dez recomendações, e o início de um envolvimento mais intenso da Organização das Nações Unidas (ONU) nas questões ambientais de caráter global.

Com a implementação do plano de ação, observa-se o início da construção de uma infra-estrutura internacional para a gestão ambiental global, na qual se destacam os seguintes eventos: criação de observatórios para monitorar e avaliar o estado do meio ambiente; maior envolvimento dos bancos multilaterais e regionais de desenvolvimento (Banco Mundial, Banco Interamericano de Desenvolvimento, etc.) e a criação do Programa das Nações Unidas para o Meio Ambiente (PNUMA), que passaria a centralizar grande parte das ações da ONU em relação às questões ambientais (Junqueira, 2002; BARBIERI, 2004).

A Conferência de Estocolmo contribuiu de maneira importante para gerar um novo entendimento sobre os problemas ambientais e a maneira como a sociedade provê a sua subsistência (Barbieri, 2004 e Mebratu, 1998). Barbieri (2004) aprofunda-se mais, observando que todos os acordos ambientais multilaterais que foram firmados depois, procuraram incluir esta nova visão a respeito das relações entre ambiente e desenvolvimento. Neste sentido, talvez uma das suas principais contribuições tenha sido a de colocar em pauta a relação entre meio ambiente e desenvolvimento, de maneira que, desde então, não seria mais possível tratar profundamente 0 desenvolvimento sem considerar o meio ambiente e vice-versa.

Desta relação entre desenvolvimento e meio ambiente é que surge o conceito, ainda recente, denominado "desenvolvimento sustentável".

\subsubsection{O período Pós-Estocolmo}

Após Estocolmo, outro marco importante, relativo à discussão acerca das questões de cunho ambientalista, foi a publicação do "Relatório Brundtlandt", mais conhecido como Nosso Futuro Comum em 1987, elaborado pela Comissão Mundial para o Desenvolvimento e Meio Ambiente (CMDM), 
órgão criado pela ONU. O relatório apresenta a definição de Desenvolvimento Sustentável, que se tornou mundialmente conhecida e que vem a ser um adequado ponto de partida na compreensão do vínculo entre desenvolvimento e meio ambiente: "desenvolvimento sustentável é aquele que atende às necessidades do presente sem comprometer a possibilidade das gerações futuras de atenderem às suas próprias necessidades" (FREY e CAMARGO, 2003 e JACOBI, 1999, BARBIERI, 2004). Jacobi (1999) destaca ainda que a divulgação do relatório representa um ponto de inflexão no debate sobre os impactos do desenvolvimento.

O relatório é o resultado de uma comissão da ONU e parte da abordagem da complexidade das causas que originam os problemas "sócioeconômicos" e ecológicos da sociedade global. Não só reforça as necessárias relações entre economia, tecnologia, sociedade e política, como também destaca a carência do reforço de uma nova postura ética em relação à preservação do meio ambiente (JACOBI, 1999), caracterizada pelo desafio de uma responsabilidade tanto entre as gerações quanto entre os integrantes da sociedade dos tempos atuais.

O Nosso Futuro Comum apresenta uma lista de ações a serem tomadas pelos Estados e também define metas a serem realizadas em nível internacional, tendo como agentes as diversas instituições multilaterais. Mebratu (1998) observa que a Comissão destaca a forte ligação entre mitigação da pobreza, melhoria ambiental e eqüidade social através do crescimento econômico sustentável.

Desde sua publicação, o Relatório Brundtland elevou o conceito de desenvolvimento sustentável a um patamar de elemento central nos discursos ambientalistas, dando margem ao surgimento de diversas interpretações, tendo grande aceitação.

\subsubsection{A fase atual: Rio-92 - um marco inicial}

A II Conferência das Nações Unidas para o Meio Ambiente e Desenvolvimento (Rio-92) realizada na cidade do Rio de Janeiro, no ano de 
1992, marca o início da fase atual das discussões ambientalistas acerca da gestão ambiental global (BARBIERI, 2004).

Este evento contou com a participação de 178 países e a aprovação de documentos importantes relativos aos problemas sócio-ambientais globais, dentre eles: a Declaração do Rio de Janeiro sobre o Meio Ambiente e o Desenvolvimento, a Convenção sobre Mudanças Climáticas, a Convenção da Biodiversidade e a Agenda 21 (principal documento produzido) (MEBRATU, 1998; FREY e CAMARGO, 2003; BARBIERI, 2004 ).

Jacobi (1999) argumenta que a conferência representou o primeiro passo de um longo processo de entendimento entre as nações sobre as medidas concretas, visando reconciliar as atividades econômicas com a necessidade de proteger o planeta e assegurar um futuro sustentável para todos os povos.

A Rio-92 reafirma a Declaração da Conferência de Estocolmo, tomandoa como base, com o objetivo de estabelecer uma nova e eqüitativa parceria global mediante a criação de novos níveis de cooperação entre os Estados, os setores-chave da sociedade e as pessoas, e procura alcançar acordos internacionais em que se respeitem os interesses de todos e proteja-se a integridade do ambiente e do desenvolvimento global, reconhecendo a natureza integral e interdependente da Terra (BARBIERI, 2004).

A Agenda 21, uma das principais contribuições desta fase, apresenta recomendações específicas para os diferentes níveis de atuação, do internacional ao organizacional (sindicatos, empresas, ONG's, instituições de ensino e pesquisa, etc.) sobre assentamentos humanos, erradicação da pobreza, desertificação, água doce, oceanos, atmosfera, poluição e outras questões sócio-ambientais constantes em diversos relatórios, tratados, protocolos e outros documentos elaborados durantes décadas pela ONU e outras entidades globais e regionais (Barbieri, 2004). Essencialmente, a Agenda 21 é uma consolidação das resoluções já tomadas por tais entidades e estruturadas a fim de facilitar sua implementação nos diversos níveis de abrangência. 
Mebratu (1998) destaca que o legado mais importante da Rio-92 foi a natureza do processo preparatório para o evento que, em muitos países envolveu diversos segmentos da sociedade, levando 0 conceito "desenvolvimento sustentável" para todos os "cantos" do mundo, assim salienta o autor.

Vinha (2004) aponta que, apesar das origens do ambientalismo ocidental remontarem há mais de duas décadas e de suas premissas básicas terem sido constituídas a partir da Conferência de Estocolmo, o marco histórico ocorreu efetivamente durante a preparação da Rio-92. A autora prossegue argumentando que essa conferência representou o resultado de um processo de discussão, registrando incontáveis manifestações a favor da sustentabilidade ambiental, com contribuições de diversas áreas do conhecimento humano. A partir deste momento, ganha mais força o fato de que o estado vigente de desenvolvimento estaria em fase terminal, estado este que cresceu em choque com a natureza.

Outro grande evento que marcou esta discussão acerca dos problemas de cunho ambientalista foi o Protocolo de Kyoto, realizado e aprovado no ano de 1997. O objetivo do Protocolo é de reduzir, entre os anos de 2008 e 2012, em média, $5,2 \%$ as emissões da atmosfera dos seis gases que provocam o efeito estufa: dióxido de carbono, metano, óxido nitroso, hidrofluocarbono, perfluorocarbono e o hexafluorocarbono de enxofre (BARSA, 2005).

Apesar de ter sido aprovado no ano de 1997 e de ter gerado grande otimismo, o Protocolo de Kyoto inicialmente foi marcado pela retirada de países importantes como os EUA, China e Índia. Após sete anos, o acordo fora ratificado juridicamente para os 141 países signatários, em 16 de fevereiro de 2005, visando estabelecer medidas concretas na luta contra o aquecimento global do planeta (Redação Terra, 2005; BARSA, 2005). Segundo Barbieri (2004), o Protocolo de Kyoto foi um grande avanço em termos de gestão ambiental, não apenas pela fixação de metas, como também, por ter criado mecanismos importantes para implementá-las (Implementação Conjunta, Comércio de Emissões e Mecanismo de Desenvolvimento Limpo). 


\subsection{Os reflexos da preocupação ambientalista no ambiente de negócios}

A partir da perspectiva histórica apresentada anteriormente, nota-se que a temática ambiental elevou-se, ao longo do tempo, a patamares de grande significância nas pautas de discussões governamentais e de órgão internacionais.

A tendência de criação de mecanismos de gerenciamento ambiental pode ser corroborada através de regulamentações firmadas em acordos estabelecidos durantes os diversos eventos internacionais realizados. Um exemplo recente é a ratificação dos itens aprovados no Protocolo de Kyoto no ano de 1997, que tiveram sua vigência estabelecida apenas em fevereiro de 2005 (BORGES, TACHIBANA e OLIVEIRA, 2005).

Para Borges e Tachibana (2005), todo este panorama, com enfoque na relação entre desenvolvimento e meio ambiente, interfere diretamente nas atividades empresariais, uma vez que estas estão no centro de todo o processo que envolve, principalmente: a utilização de recursos naturais, a geração de resíduos e a capacidade de suporte do planeta (tanto no suprimento de recursos, quanto na recepção de resíduos).

A figura 1 sintetiza esta visualização evolutiva da discussão ambientalista, marcada em três fases distintas.

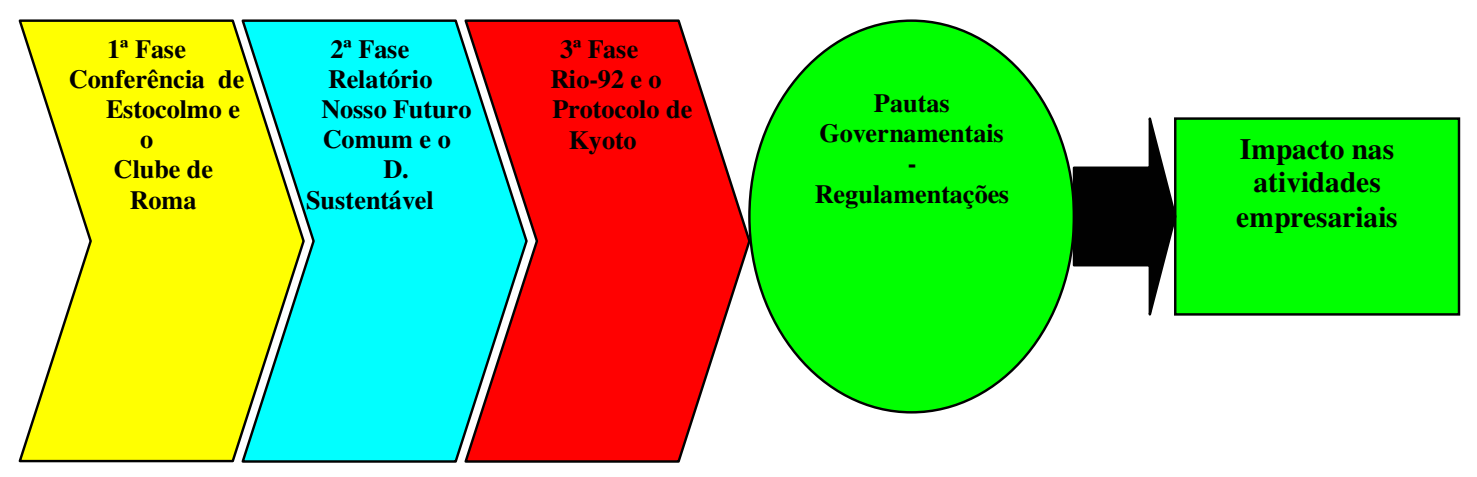

Figura 1 - quadro evolutivo das questões ambientais

Hoffman (1999 e 2001), através de sua pesquisa sobre a indústria química e petrolífera entre os anos 1960 e 1993, procurou entender como estas indústrias moveram-se de uma postura de vertiginosa resistência ao 
ambientalismo para uma postura pró-ativa e as razões que permearam esta mudança. Com o estudo dos atores e das instituições associadas a cada indústria, este autor identificou quatro períodos distintos no ambientalismo corporativo:

1. Ambientalismo industrial (1960-70) - centralizava-se na resolução interna dos problemas como um adjunto para a área de operações (havia um otimismo tecnológico de que os problemas seriam resolvidos sem que houvesse a necessidade de intervenção governamental)

2. Ambientalismo regulatório (1970-82) - cujo foco era a conformidade com as regulamentações, dada a imposição externa de novas leis ambientais cada vez mais rigorosas.

3. Ambientalismo como responsabilidade social (1982-88) - centrava-se na redução da poluição e minimização de resíduos dirigidos externamente por pressões de movimentos ambientalistas e algumas iniciativas voluntárias.

4. Ambientalismo Estratégico (19988-93) - o foco se dá na integração de estratégias ambientais pró-ativas a partir da administração superior devido a questões econômicas que passam a se desenvolver associadas às questões ambientas das empresas.

Souza (2002) salienta que a conclusão que se chega é que a internalização das questões ambientais pelas empresas é um produto da coevolução de instituições externas e das estruturas e estratégias internas das firmas.

O meio ambiente era tido, tradicionalmente, como uma fonte inesgotável de recursos naturais. Com o advento da industrialização, esta idéia tornou-se ainda mais abrangente, e o meio ambiente passou também a ser recipiente de resíduos gerados pelas atividades industriais (BORGES e TACHIBANA, 2005).

A discussão atual foca tanto a questão da utilização desenfreada dos recursos naturais, quanto a geração de resíduos no que diz respeito à capacidade de suporte de nosso planeta. 
O aprofundamento das questões teóricas relacionadas à integração da variável ambiental na empresa apresenta-se intensamente na contemporaneidade e será discutido no capítulo seguinte. 


\section{A variável ambiental no ambiente empresarial}

A história tem mostrado que, ao longo das últimas décadas, uma nova consciência acerca das questões relacionadas ao meio ambiente vem emergindo. Este fato representa um grande desafio para as organizações que visualizam, por sua vez, necessidades no tocante de uma adequação a um novo perfil ecológico exigido pela sociedade e autoridades.

Souza (2002) argumenta que a questão ambiental fora tratada por muitos, no passado, como uma questão ideológica de grupos ecologistas que não aceitavam a sociedade de consumo moderna e que essa questão, atualmente, assume um papel cada vez maior no ambiente empresarial.

Para Donaire (1994), a nova consciência ambiental, surgida a partir das transformações culturais que começaram a aflorar nas décadas de 60 e 70, ganhou dimensão e situou a proteção ao meio ambiente como um dos princípios fundamentais do homem contemporâneo.

As dimensões econômicas e mercadológicas das questões ambientais têm se tornado cada vez mais relevantes, representando custos e/ou benefícios, limitações e/ou potencialidades, ameaças e/ou oportunidades para as empresas (SOUZA, 2002). Este autor prossegue apontando que tal perspectiva pode ser corroborada em estudos publicados em periódicos destinados ao público empresarial e financeiro, nos quais o vínculo de empresas e mercados com as questões ambientais está alcançando altos patamares de significância.

Uma mudança muito grande pôde ser observada no ambiente em que as empresas operam: as empresas que antes eram vistas apenas como instituições econômicas com responsabilidades referentes a resolver problemas econômicos fundamentais (o que produzir, como produzir e para quem produzir), têm presenciado o surgimento de novos papéis que devem ser 
desempenhados, como resultado das alterações no ambiente em que operam (DONAIRE, 1999 p. 1).

Muitos fatores têm se apresentado como impulsionadores desta reformulação do ambiente empresarial. Numa perspectiva convencional, a instituição empresarial era considerada apenas por sua função econômica, na qual a única responsabilidade que lhe cabia era a de maximizar os lucros e minimizar seus custos ou pouco além disto. Os aspectos sociais e políticos não eram considerados variáveis significativas nos processos de tomada de decisões. Donaire (1999) justifica esta visão com a seguinte afirmação que era comum aos empresários que defendiam este ponto de vista: "o que é bom para a empresa, é bom para a sociedade".

Para Barbieri (2004), a solução dos problemas ambientais, ou sua minimização, exige uma nova atitude de empresários e administradores, que devem abranger e levar em consideração o meio ambiente em suas decisões e adotar concepções administrativas e tecnológicas que contribuam para ampliar a capacidade de suporte do planeta. Em termos gerais, espera-se que as empresas deixem de ser problemas e façam parte das soluções envolvendo o meio ambiente.

Numa perspectiva histórica, como abordado anteriormente, desde a Conferência de Estocolmo, em 1972, as questões ambientais foram inseridas de forma prioritária e definitiva na agenda internacional, estando cada vez mais presentes nos diferentes elementos que exercem influência nas decisões empresariais.

A questão ambiental, em termos de significância, passou a ser tratada, ao longo do tempo, não mais apenas como uma "agenda negativa" (SOUZA, 2002), mas como um fator atrativo em termos competitivos. Isso se acentua sobretudo com o surgimento de novos conceitos como Desenvolvimento Sustentável e Ecodesenvolvimento, no campo das teorias desenvolvimentistas; e Produção Mais Limpa (PML) e Gerenciamento Ambiental da Qualidade Total (TQEM), no campo empresarial dentre outros (SOUZA, 2002; EPELBAUM, 2004). 


\subsection{A gestão ambiental e suas perspectivas}

As questões relativas ao meio ambiente têm sido crescentemente incorporadas aos mercados e às estruturas sociais e regulatórias da economia, passando a ser um elemento cada vez mais considerado nas estratégias de crescimento das empresas, seja por gerar ameaças, como também oportunidades empresariais (DONAIRE, 1999; BARBIERI, 2004).

Barbieri (2004) define os termos administração ou gestão do meio ambiente, ou simplesmente gestão ambiental, como as diretrizes e as atividades administrativas e operacionais, tais como planejamento, direção, controle, alocação de recursos e outras realizadas com o objetivo de obter efeitos positivos sobre o meio ambiente, quer reduzindo ou eliminando os danos ou problemas causados pelas ações humanas.

Para este autor, qualquer proposta de gestão ambiental inclui no mínimo três dimensões, a saber: 1) a dimensão espacial, que concerne à área na qual se espera que as ações de gestão tenham eficácia; 2) a dimensão temática, que delimita as questões ambientais às quais as ações se destinam; e 3) a dimensão institucional, relativa aos agentes que tomaram as iniciativas de gestão.

\subsubsection{Os indutores da gestão ambiental}

Souza (2002) aponta um quadro evolutivo no tocante à incorporação de parâmetros ambientais às estratégias empresariais. Para Hoffman (2000), os governos e ativistas sociais têm sido historicamente os mais proeminentes elementos direcionadores das práticas ambientais corporativas.

Barbieri (2004) pontua que a gestão ambiental começou efetivamente pelos governos dos Estados nacionais e desenvolveu-se à medida que os problemas foram surgindo. $\mathrm{O}$ autor prossegue argumentando que as primeiras manifestações de gestão ambiental procuravam solucionar apenas problemas de escassez de recursos e que, somente após a Revolução Industrial, os problemas concernentes à poluição começaram a ser tratados de modo sistemático. 
Por um longo período, as iniciativas dos governos eram predominantemente de cunho corretivo, produzindo ações fragmentadas apoiadas em medidas pontuais, pouco integradas.

Souza (2002) e Barbieri (2004) destacam que a partir da década de 1970 começam a surgir iniciativas governamentais que procuram tratar as questões ambientais de modo integrado, visando à introdução de abordagens preventivas dos atores envolvidos.

A gestão ambiental pública é ação do Poder Público, conduzida segundo uma política pública ambiental. Para tanto são usados alguns instrumentos, como forma de induzir o comportamento dos atores sociais, com vistas à produção de efeitos desejáveis ao meio ambiente.

\begin{tabular}{|c|c|}
\hline Gênero & Espécies \\
\hline Comando e Controle & $\begin{array}{l}\text { - Padrão de emissões } \\
\text { - Padrão de qualidade } \\
\text { - Padrão de desempenho } \\
\text { - Padrões tecnológicos } \\
\text { - Proibições e restrições sobre produção, } \\
\text { comercialização e uso de produtos e } \\
\text { processos. } \\
\text { - Licenciamento ambiental } \\
\text { - Zoneamento ambiental } \\
\text { - Estudo prévio de impacto ambiental }\end{array}$ \\
\hline Econômico & $\begin{array}{l}\text { - Tributação sobre poluição } \\
\text { - Tributação sobre uso de recursos } \\
\text { naturais } \\
\text { - Incentivos fiscais para reduzir emissões } \\
\text { e conservar recursos } \\
\text { - Financiamentos em condições especiais } \\
\text { - Criação e sustentação de mercados de } \\
\text { produtos ambientalmente saudáveis } \\
\text { - Permissões negociáveis } \\
\text { - Sistema de depósito-retorno } \\
\text { - Poder de compra do Estado }\end{array}$ \\
\hline Outros & $\begin{array}{l}\text { - Apoio ao desenvolvimento científico e } \\
\text { tecnológico } \\
\text { - Educação ambiental } \\
\text { - Unidades de conservação } \\
\text { - Informações ao público }\end{array}$ \\
\hline
\end{tabular}

Quadro 1 - Instrumentos de Política Ambiental

Fonte: Barbieri (2004, p. 61) 
Os instrumentos de comando e controle são também denominados instrumentos de regulação direta, com o objetivo de alcançar ações que degradam o meio ambiente, limitando e condicionando o uso de bens, a realização de atividades e o exercício de liberdades individuais em benefício da sociedade como um todo. Podem ser divididos em três principais grupos: padrão de qualidade ambiental, padrão de emissão e padrão ou estágio tecnológico.

Os instrumentos econômicos ou fiscais procuram influenciar o comportamento das pessoas e organizações em relação ao meio ambiente utilizando medidas que representem benefícios ou custos adicionais para essas. Podem ser agrupadas em dois tipos: instrumentos fiscais e instrumentos de mercado.

Para Barbieri (2004, p.71), cada tipo de instrumento tem suas vantagens e desvantagens, seus defensores e detratores. Para este autor, os instrumentos econômicos têm sido apontados como mais aptos a induzir comportamentos mais dinâmicos por parte dos agentes privados, comparativamente aos de comando e controle. Estes últimos são criticados pelo peso que exercem sobre o Estado, uma vez que sua eficácia depende de um aparato institucional dispendioso.

Schmidheiny (1992), neste contexto, argumenta que os instrumentos econômicos são mais apropriados aos mercados competitivos e esses mais apropriados para promoverem o desenvolvimento sustentável, pois nestes mercados os preços refletem os custos dos recursos ambientais. Para este autor, os instrumentos de comando e controle, na medida em que implicam na adesão às exigências específicas, tendem a perpetuar uma dada situação em vez de induzir a sua melhoria constante.

Segundo a Cepal (1995), teoricamente tem sido evidenciado que os incentivos econômicos possuem maior eficácia para se alcançar objetivos ambientais, propiciando estímulos permanentes para que as empresas deixem de gerar poluição, ao passo que, no comando e controle, uma vez alcançado os níveis estipulados pelas normas regulatórias, as empresas tenderiam a reduzir esforços ambientais. Desta forma, os instrumentos econômicos contribuiriam também para estimular as atividades de $P \& D$, induzindo os 
agentes à incorporar princípios de melhoria contínua dos parâmetros ambientais.

Porter e Linde (1999) também se apresentam como defensores desta perspectiva sobre a utilização de instrumentos de regulamentação ambiental em um contexto positivo, no qual, os regimentos ambientais adequados podem potencializar o uso mais eficiente de recursos, contrariando a visão tradicional que conclama um antagonismo irreconciliável entre economia e ecologia.

O problema central não seria a regulamentação em si, mas o modo como esta é formulada. Na prática, as vantagens anteriormente citadas, nem sempre são observadas (PORTER e LINDE, 1999; BARBIERI, 2004). A atribuição de tributos, que se transformem em incentivos para alterar o comportamento de empresários e consumidores, não se consolida como uma tarefa simples; se forem elevados, poderiam inviabilizar negócios, se forem baixos, não provocariam as mudanças desejadas. Somado a isto, para que os tributos sejam justos e eficazes, esses deveriam ser estabelecidos de acordo com as circunstâncias específicas de cada setor econômico.

Por fim, Barbieri (2004) aponta que uma política ambiental consistente deve se valer de todos os instrumentos possíveis e estar atenta aos efeitos sobre a competitividade das empresas, devendo ser eficiente para prevenir danos ambientais sem, no entanto, prejudicar os fatores competitivos das empresas.

\subsection{A gestão ambiental na empresa}

Para Barbieri (2004, p.99), a solução dos problemas ambientais, ou sua mitigação, exige uma nova postura dos empresários e administradores, que devem passar a considerar o meio ambiente em suas decisões e adotar concepções administrativas e tecnológicas que contribuam para ampliar a capacidade de sustentabilidade do planeta.

A experiência mostra que tal atitude dificilmente surge espontaneamente; as preocupações ambientais das empresas são influenciadas por três grandes forças, como mostra a Figura 2. 
Sanches (2000) aponta que seja como consumidores, trabalhadores, ou ainda por meio do governo ou da mídia, a sociedade tem pressionado para que as empresas incorporem novos valores ao seus procedimentos operacionais.

Entretanto, a internalização da variável ecológica no âmbito dos negócios não ocorre de forma homogênea, variando entre as unidades produtivas (Donaire, 1994), seja porque a consideração da variável ambiental está associada à natureza do negócio da empresa, seja porque depende do grau de conscientização da alta administração em matéria ambiental (Corazza, 2003). Por isso, a maior parte dos pesquisadores em gestão ambiental avalia a conscientização ambiental empresarial à luz de diversos cenários e quadros evolutivos, que traduzem a maturidade de determinada organização para com o tratamento das questões ecológicas (JABBOUR e SANTOS, 2005).

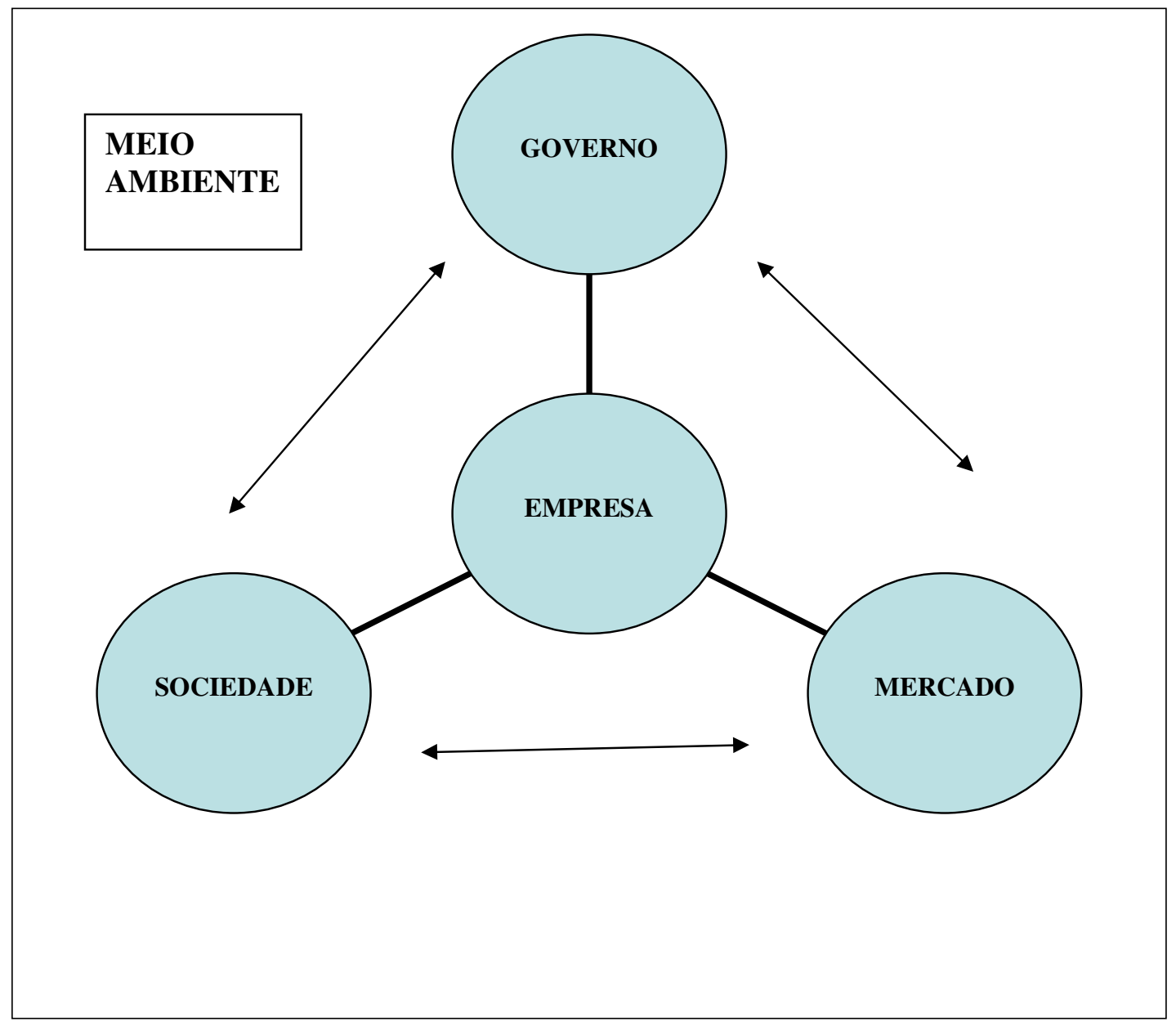

Figura 2 - Os indutores da gestão ambiental empresarial Adaptado de Barbieri (2004) 
Porter (1985) aponta que diversos agentes, ao longo do tempo, passaram a intervir dentro da estrutura tradicional de análise competitiva da indústria, como ONG's, comunidades, órgãos governamentais, investidores, seguradoras e a mídia, com forças distintas. De um lado, comunidades, órgãos governamentais e seguradoras cobram principalmente processos limpos; de outro, consumidores mais conscientes selecionam produtos menos impactantes e/ou com processos menos impactantes ambientalmente; por fim, as ONG's e os investidores cobram processos e produtos mais limpos. De qualquer maneira, as condições ambientais para a compra de produtos, empréstimos financeiros, avaliação de riscos de mercado, avaliação do valor de ações, venda de ativos, contratação de seguros, obtenção de licença para operar e a manutenção de uma imagem de empresa "cidadã", resultam em pressões sobre todas as operações e produtos das empresas, ao longo de seu ciclo completo de vida (SOUZA, 2002; EPELBAUM, 2004).

Azzone, Bertelè \& Noci (1997) destacam que as organizações estão diante de uma variedade de pressões, que tendem a induzir os gerentes a considerar os tópicos ambientais como importantes parâmetros para usas decisões de negócio.

Sanches (2000) ressalta que as empresas industriais, que buscam manter ou melhorar suas posições competitivas, se deparam cada vez mais com a exigência de novas posturas em relação às variáveis ambientais.

A gestão ambiental, segundo Epelbaum (2004), pode ser entendida como a parte da gestão empresarial que cuida da identificação, avaliação, controle, monitoramento e redução dos impactos ambientais a níveis prédefinidos. Em complemento a esta perspectiva, Rohrich e Cunha (2004) destacam que a gestão ambiental abrange o conjunto de políticas e práticas administrativas e operacionais que levam em conta a saúde e a segurança das pessoas e a proteção do meio ambiente por meio da eliminação ou mitigação de impactos e danos ambientais decorrentes do planejamento, implantação, operação, ampliação, realocação ou desativação de empreendimentos ou atividades, incluindo-se todas as fases do ciclo de vida do produto.

Dessa forma, pode-se dizer que a gestão ambiental envolve as atividades de planejamento e organização do tratamento da variável ambiental 
pela empresa, objetivando-se alcançar metas ecológicas específicas (Seiffert, 2005).

\footnotetext{
"Gestão ambiental é o conjunto de rotinas e procedimentos que permite a uma organização administrar as relações entre as suas atividades e o meio ambiente que as abriga, atentando para as expectativas das partes interessadas (stakeholders) (REIS, 1997, p.10)."
}

Barbieri (2004) apresenta uma definição sobre modelos de gestão ambiental empresarial que se apóiam em três critérios de desempenho, a saber: eficiência econômica, eqüidade social e respeito ao meio ambiente. Estes critérios devem ser considerados simultaneamente em qualquer proposta de gestão sócioambiental.

Assim, tais modelos devem contribuir para gerar renda e riqueza, que são os objetivos básicos das empresas, minimizando seus impactos ambientais adversos, maximizando os benefícios, tornando a sociedade justa.

O conceito de sustentabilidade, que os grupos engajados ecologicamente denominam, diz respeito à condição sistêmica, segundo a qual, em nível regional e planetário, as atividades humanas não devem interferir nos ciclos naturais em que se baseia tudo o que a capacidade do planeta permite e, ao mesmo tempo, não devem empobrecer seu capital natural que será transmitido às gerações futuras (EPELBAUM, 2004).

Esta abordagem não é a que se encontra corriqueiramente na gestão empresarial, mas este conceito, segundo Elkington (2001), pode ser ampliado, formando a Teoria dos Três Pilares ("Tripple Bottom Line") desenvolvida por este. A teoria define que a sociedade depende da economia, e a economia depende do ecossistema global, cuja saúde representa o pilar derradeiro; os três podendo ser representados como placas sobrepostas, interferindo umas nas outras. Epelbaum (2004) postula que diante desta visão, uma empresa pode ser considerada sustentável se gerenciar e conseguir bons resultados nas áreas econômica, ambiental e social, concomitantemente. 


\subsubsection{Sistemas de gestão ambiental}

Sistema de gestão ambiental (SGA) é um conjunto de atividades administrativas e operacionais inter-relacionadas para abordar os problemas ambientais atuais ou para evitar seu surgimento (REIS, 1997; DONAIRE, 1999; BARBIERI, 2004).

Barbieri (2004, p.137) evidencia que um SGA requer a formulação de diretrizes, definição de objetivos, coordenação de atividades e avaliação de resultados. Reis (1997) observa que, torna-se necessário o envolvimento de diferentes setores da empresa para tratar das questões ambientais de modo integrado.

Neste contexto, alguns elementos se apresentam como fundamentais: 0 comprometimento da alta gerência; o estabelecimento de uma política ambiental corporativa; procedimentos que permitam a avaliação dos impactos ambientais atuais e futuros; planos fixando objetivos e metas; instrumentos para acompanhar e avaliar as ações planejadas e o desempenho do SGA como um todo (DONAIRE, 1999 e BARBIERI, 2004).

No âmbito empresarial, a família de normas ISO 14.000 apresenta-se como a mais utilizada.

Reis (1997) afirma que a ISO 14.000 aborda a gestão ambiental por meio de uma série de normas sobre sistemas de gestão ambiental, auditoria ambiental, avaliação de desempenho ambiental, avaliação do ciclo de vida do produto, rotulagem ambiental e aspectos ambientais em normas de produtos.

A NBR ISO 14.004 fornece elementos para a empresa criar e aperfeiçoar o seu SGA e a NBR ISO 14.001 é uma norma que contém os requisitos que podem ser objetivamente auditados para fins de certificação, registro ou autodeclaração (REIS, 1997; BARBIERI, 2004).

De acordo com a NBR ISO 14.001, o SGA é parte integrante do sistema de gestão global que inclui a estrutura organizacional, atividades de planejamento, responsabilidades, práticas, procedimentos, processos e recursos para desenvolver, implementar, atingir, analisar criticamente e manter a política ambiental. 


\subsubsection{Diferentes abordagens para a gestão ambiental empresarial}

A atuação das empresas com relação aos problemas ambientais decorrentes de suas atividades pode ocorrer em três abordagens distintas, denominadas por Barbieri (2004), controle da poluição, prevenção da poluição e incorporação das questões ambientais na estratégia empresarial.

\begin{tabular}{|c|c|c|c|}
\hline \multirow{2}{*}{ CARACTERÍSTICAS } & \multicolumn{3}{|c|}{ ABORDAGENS } \\
\hline & Controle da Poluição & Prevenção da Poluição & Estratégia \\
\hline Preocupação básica & $\begin{array}{l}\text { Cumprimento da } \\
\text { legislação e repostas às } \\
\text { pressões da comunidade }\end{array}$ & $\begin{array}{l}\text { Uso eficiente dos } \\
\text { insumos }\end{array}$ & Competitividade \\
\hline Postura típica & Reativa & Reativa e Pró-ativa & Reativa e Pró-ativa \\
\hline \multirow{3}{*}{ Ações Típicas } & Corretivas & Corretivas e preventivas & $\begin{array}{l}\text { Corretivas, } \\
\text { preventivas e } \\
\text { antecipatórias }\end{array}$ \\
\hline & $\begin{array}{l}\text { Tecnologias de } \\
\text { remediação e de controle } \\
\text { no final do processo (end } \\
\text { of pipe) }\end{array}$ & $\begin{array}{c}\text { Conservação e } \\
\text { substituição de insumos }\end{array}$ & $\begin{array}{c}\text { Antecipação de } \\
\text { problemas e } \\
\text { captura de } \\
\text { oportunidades } \\
\text { utilizando soluções } \\
\text { de médio e longo } \\
\text { prazos }\end{array}$ \\
\hline & $\begin{array}{c}\text { Aplicação de normas de } \\
\text { segurança }\end{array}$ & $\begin{array}{c}\text { Uso de tecnologias } \\
\text { limpas }\end{array}$ & $\begin{array}{c}\text { Uso de tecnologias } \\
\text { limpas }\end{array}$ \\
\hline $\begin{array}{l}\text { Percepção dos } \\
\text { empresários e } \\
\text { administradores }\end{array}$ & Custo Adicional & $\begin{array}{l}\text { Redução de custo e } \\
\text { aumento da } \\
\text { produtividade }\end{array}$ & $\begin{array}{l}\text { Vantagens } \\
\text { competitivas }\end{array}$ \\
\hline $\begin{array}{l}\text { Envolvimento da alta } \\
\text { direção }\end{array}$ & Esporádico & Periódico & $\begin{array}{l}\text { Permanente e } \\
\text { sistemático }\end{array}$ \\
\hline Áreas envolvidas & $\begin{array}{c}\text { Ações ambientais } \\
\text { confinadas nas áreas } \\
\text { produtivas }\end{array}$ & $\begin{array}{l}\text { as principais ações } \\
\text { ambientais continuam } \\
\text { confinadas nas áreas } \\
\text { produtivas, mas há } \\
\text { crescente envolvimento } \\
\text { de outras áreas }\end{array}$ & $\begin{array}{c}\text { Atividades } \\
\text { ambientais } \\
\text { disseminadas pela } \\
\text { organização } \\
\text { Ampliação das } \\
\text { ações ambientais } \\
\text { para toda a cadeia } \\
\text { produtiva }\end{array}$ \\
\hline
\end{tabular}

Quadro 2 - Diferentes abordagens da gestão ambiental empresarial Fonte: Barbieri (2004)

Alguns autores abordam a perspectiva da gestão ambiental empresarial de maneira complementar à perspectiva apresentada no quadro anterior.

Maimon (1994) propõe que a resposta empresarial à crescente pressão social em matéria ambiental pode ser analisada em três movimentos: 
1. Adaptação da empresa à regulamentação ou exigência do mercado, incorporando equipamentos de controle de poluição nas saídas, sem modificar a estrutura produtiva e o produto;

2. Adaptação à regulamentação ou exigências do mercado, modificando os processo e/ou produtos (inclusive embalagem), objetivando-se prevenir a poluição e problemas que prejudiquem a estratégia empresarial;

3. Antecipação aos problemas ambientais futuros, ou seja, adoção de um comportamento pró-ativo e de busca pela eco-excelência empresarial, cujo princípio é integrar a função ambiental ao planejamento estratégico da empresa.

Azzone, Bertelè \& Noci (1997) consideram a sustentabilidade sob quatro diferentes enfoques estratégicos organizacionais:

1. Estratégia ambiental passiva, "lobbying-based": os gestores que adotam este tipo de estratégia percebem a variável ambiental como uma significante ameaça às suas posições competitivas, devido à crescente preocupação da opinião pública e reguladores. A partir disso, esses objetivam limitar potenciais investimentos em melhorias ambientais, influenciando a evolução do contexto externo e, em particular, reduzindo o nível de mudanças nos requerimentos ambientais.

2. Estratégias ambientais reativas: envolvem principalmente reações a estímulos externos - movimentos ambientalistas, governos/regulamentações e outras firmas operando em outros campos.

3. Estratégia ambiental antecipatória: implica que o "timing" das iniciativas ambientais é considerado uma fonte primária de vantagem competitiva futura pelas empresas. Prevendo uma provável evolução do mercado ou das regulamentações ambientais, as empresas investem em "novas" tecnologias que possibilitarão a essas antecipar as futuras expectativas dos consumidores ou as necessidades do mercado e ganhar "an early 
mover" vantagem competitiva dos efeitos da aprendizagem de uma acumulação de conhecimentos.

4. Estratégia ambiental baseada em inovações: a variável ambiental é vista como a mais importante prioridade competitiva e as soluções, baseadas em inovações, são "tomadas (sought)" envolvendo a introdução de novas tecnologias que alavanquem radicalmente a performance ambiental das tecnologias correntes ou a criação de novas necessidades de mercado como conseqüência de produtos amigáveis ambientalmente.

Para Donaire (1999), a resposta da indústria ao desafio ecológico pode ser analisada por três estágios, muitas vezes superpostos. A primeira fase é chamada de controle ambiental na saída (end of pipe), tais como em chaminés e redes de esgotos, mantendo a estrutura produtiva já existente; o que nem sempre se mostra eficaz, uma vez que os benefícios desta reação são freqüentemente contestados pela sociedade civil e pelo próprio empresariado. Segundo o autor, estas contestações fomentaram um novo tipo de reação, na qual a variável ambiental é integrada nas práticas e processos produtivos, sendo considerada atividade da função de produção. Não obstante, com o crescimento da variável ecológica como fator competitivo para as empresas, desenvolveu-se um novo estágio de integração da questão ambiental no âmbito dos negócios, chamado de controle ambiental na gestão administrativa, no qual a proteção ao meio ambiente deixa de ser uma exigência punida com multas e sanções e se inscreve em um quadro de ameaças e oportunidades em que as conseqüências tem impacto sobre a sobrevivência da organização.

Para Corazza (2003), a estrutura da unidade produtiva pode ser alterada de duas formas. A primeira se relaciona com a integração pontual da variável ambiental, a qual é caracterizada pela criação da função, cargo ou departamento ambiental, corroborando a centralização dessa iniciação funcional. Jabbour e Santos (2005) frisam que a integração pontual pode se traduzir em um sistema de gestão ambiental pouco eficiente, que exclui a possibilidade de desenvolvimento pró-ativo da perspectiva ecológica.

A segunda forma seria a integração matricial da gestão ambiental, na qual seria observado um processo de mobilização dos setores internos da 
organização, necessários ao planejamento, execução, revisão e desenvolvimento da política ambiental (Corazza, 2003), envolvendo, principalmente, as áreas de recursos humanos, produção, gestão e pesquisa e desenvolvimento (P\&D). Este tipo de integração é encontrada em organizações que têm como meta a excelência em adequação ambiental, comumente impulsionadas pela implantação de sistemas baseados em normas das série ISO 14000, que norteiam a empresa para uma busca contínua e crescente da qualidade ambiental.

Sanches (2000) aponta que a integração da variável ambiental na empresa pode ocorrer de duas maneiras, a saber:

1. Reativa, ativada por ameaças tecnológicas, punições e sanções legais;

2. Pró-ativa, mediante a incorporação da problemática ambiental no processo de formulação de metas e objetivos de longo prazo da organização.

Para a autora, as empresas que adotam posturas pró-ativas em relação ao meio ambiente incorporam os fatores ambientais em suas metas, políticas e estratégias, considerando os riscos e os impactos ambientais não só de seus processos produtivos como também de seus produtos. Neste tipo de abordagem, a proteção ambiental passa a fazer parte do objetivo de negócios das empresas, passando o meio ambiente a não ser encarado como mero custo adicional, mas como uma possibilidade de lucros, em um quadro de ameaças e oportunidades para a empresa, idéia compartilhada por Donaire (1999).

No contexto pró-ativo, a variável ecológica assume um papel competitivo dentro das organizações. Maimon (1996 p. 22) classificou as empresas que abordam a gestão ambiental como fator condicionante de sua competitividade, de organizações possuidoras do "comportamento ético ambiental". Ainda segundo a autora, este modelo passa a tratar o meio ambiente como uma nova oportunidade de negócios, tanto do ponto de vista tecnológico quanto organizacional. 
A postura pró-ativa pode ser definida pelo comportamento empresarial que abarca os objetivos ambientais em todos os níveis hierárquicos - da cúpula ao chão-de-fábrica - redefinindo competências e responsabilidades (JABBOUR E SANTOS, 2205). Em outras palavras, a dimensão ecológica não é apenas mais uma variável na determinação dos planos empresariais; ela se torna uma prioridade e todas as outras áreas funcionais das organizações passam a gravitar sobre pressupostos ecológicos (HUNT e AUSTER, 1990).

Para Miranda et. al. (1997), a ênfase na oportunidade de antecipar-se ou de ser pró-ativo em relação às questões ambientais envolve decisões estratégicas tais como investimentos em pesquisa e desenvolvimento de novos produtos e processos que geram políticas, metas e planos de ação que nortearão a empresa.

Segundo Rohrich e Cunha (2004), a gestão ambiental pró-ativa se consolida pela existência de três fatores, a saber:

- Envolvimento da alta gerência para com a problemática ambiental;

- $\quad$ Autoridade ambiental formalizada;

- Influência da variável ambiental no processo de formulação da estratégia da empresa.

Souza (2002) afirma que, na década de 1990, muitas firmas começaram a integrar o meio ambiente em suas estratégias empresariais, havendo o surgimento de um novo e estratégico paradigma ambiental. $\mathrm{O}$ autor prossegue argumentando que a partir disso, as ações das firmas na área ambiental se tornaram mais pró-ativas e passaram a ser utilizadas como estratégias competitivas, vinculando-se à boa performance ambiental, principalmente à melhoria na reputação das empresas.

Desde o início da década de 1990, a realidade do ambientalismo dentro do mundo dos negócios tem se tornado mais complexa que a simples conformidade com as leis ou a responsabilidade social. Proteção ambiental e competitividade econômica têm se entrelaçado desde então. Aquilo que anteriormente fora dirigido por pressões que estavam fora do mundo dos negócios é atualmente norteado por interesses que existem dentro dos 
ambientes econômico, político, social e mercadológico das empresas. Muitas organizações, ao obterem boa performance ambiental associada à boa gestão operacional, baixo risco financeiro e boas perspectivas de sucesso econômico futuro, estão começando a influenciar as normas de práticas corporativas e estão transformando o ambientalismo, de algo externo para algo que está dentro do sistema de mercado e que é central para os objetivos da empresa (HOFFMAN, 2000).

Desta forma, uma variedade de situações do ambiente institucional passou a dirigir as estratégias ambientais das empresas, tais como: investidores e acionistas, que estariam interessados em correlações positivas entre as performances econômica e ambiental; bancos que estariam associando performances ambientais ruins a risco financeiro mais elevado; e associações comerciais, educacionais e religiosas que passaram a institucionalizar determinadas demandas ambientais (SOUZA, 2002).

\subsection{A variável ambiental e as questões competitivas}

O setor industrial é um dos que mais provoca danos ao meio ambiente, seja por seus processos produtivos ou pela fabricação de produtos poluentes e/ou que tenham problemas de disposição final após sua utilização.

Tópicos relacionados à competitividade e ao meio ambiente ganharam importância crescente entre os anos 80 e 90. Com a intensificação do processo de globalização financeira e produtiva da economia mundial, e o conseqüente aumento dos fluxos de comércio internacional, as barreiras tarifárias foram gradativamente substituídas por barreiras não-tarifárias.

Lustosa (2004) destaca que o crescimento da produção capitalista depende de novos mercados e, portanto, da criação de novas necessidades para os consumidores. Desta forma, as necessidades da população aumentam juntamente com a escala de produção industrial, com a demanda por recursos naturais e com os rejeitos dos processos produtivos.

Esta autora prossegue argumentando que pode-se perceber o trade off entre crescimento econômico e preservação do meio ambiente. De um lado, o crescimento econômico melhorou as condições de vida da população, gerando 
maior quantidade de bens e serviços disponíveis para a satisfação das necessidades; de outro lado, provocou problemas ambientais, que não se restringiram à atividade industrial.

Após algumas décadas de debate sobre os limites ambientais do crescimento econômico, percebeu-se que não foi o crescimento que chagou ao seu limite, mas o padrão tecnológico até então adotado pelos países industrializados.

Young e Lustosa (2001) e Lustosa (2004) indicam que um problema central neste contexto é o modo de indução de mudanças tecnológicas na direção de tecnologias mais limpas a fim de se obter uma sustentabilidade ambiental. Além do mais, a mudança tecnológica na direção desta sustentabilidade depende de outros fatores não econômicos, como desenvolvimento de capacidades específicas da firma, infra-estrutura e mudanças institucionais.

Os autores sobressaltam que a relação entre competitividade e preservação do meio ambiente tornou-se objeto de debates intensos, no quais, segundo eles, pôde-se identificar duas vertentes bem distintas: a primeira, que defendia a existência de um trade-off, como abordado acima; e a segunda, vislumbrando sinergias entre competitividade e preservação do meio ambiente, intitulada pela literatura pertinente de "hipótese de Porter", baseada em Porter e Linde (1995 e 1999).

O argumento desta última vertente era de que a imposição de regulamentações ambientais adequadas poderiam estimular as empresas a adotarem inovações que reduzissem os custos totais de um produto ou aumentarem o seu valor. Assim, no momento em que as empresas visualizam as regulamentações como um desafio, passam a desenvolver soluções inovadoras e, portanto, melhoram a sua competitividade (PORTER e LINDE, 1999).

Desta forma, através de regulamentações mais estreitas, os gestores seriam forçados a prestar especial atenção àqueles aspectos de seus negócios que podem estar sendo negligenciados. Tal atenção pode gerar um incremento 
de lucratividade através da redução de custo, inovações e/ou vantagem competitiva em mercados estrangeiros.

Souza (2002) destaca que os pontos referentes aos valores ecológicos que anteriormente eram dirigidos por pressões que estavam fora das linhas fronteiriças do mundo dos negócios estão atualmente direcionados por interesses que existem dentro dos ambientes econômico, político, social e mercadológico das empresas.

Muitos autores, adeptos desta abordagem, desenvolveram diversos trabalhos interessantes. Para Epelbaum (2004), os fatores da gestão ambiental que influenciam no sucesso e na competitividade empresarial podem ser estruturados em dois grupos de resultados finais, a saber:

- $\quad$ resultados da gestão ambiental em processos

- $\quad$ resultados da gestão ambiental de produtos

Os resultados esperados pela gestão ambiental em processos estão ligados à busca contínua por processos produtivos mais limpos. Já a expectativa com relação aos resultados da gestão ambiental em produtos concerne ao desenvolvimento de produtos ambientalmente adequados e seguros. A Figura 2 ilustra os principais fatores da gestão ambiental e suas respectivas ferramentas.

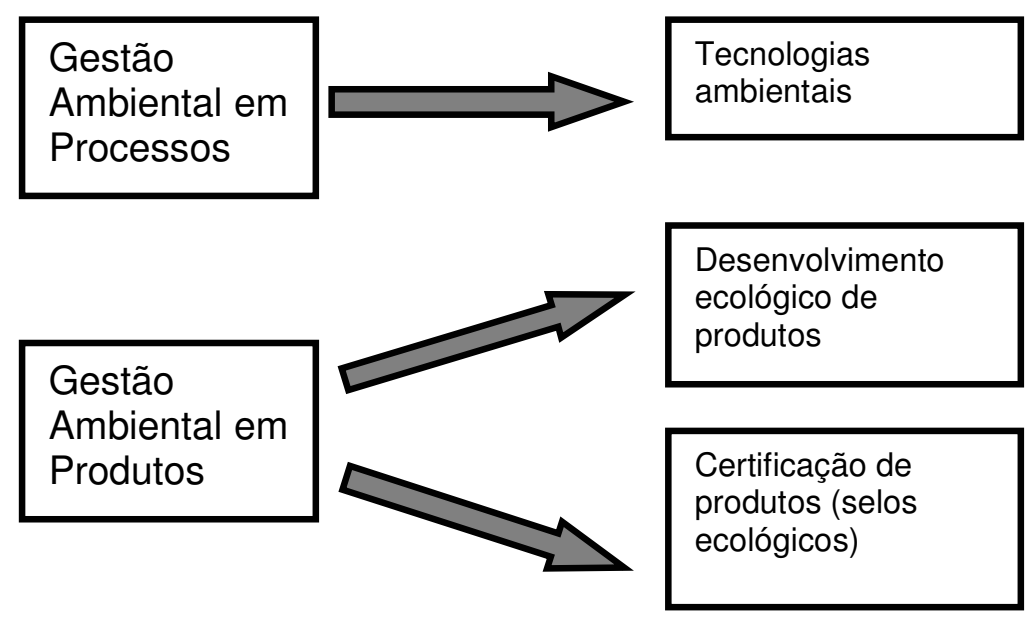

Figura 3 - Fatores e ferramentas de gestão ambiental Fonte: Epelbaum (2004) 
Rosen (2001) afirma que o paradigma empresarial de desenvolvimento de processo e produto está sendo repensado, tendo em vista as problemáticas pertinentes à gestão ambiental. Essa alteração paradigmática gera diversas formas de inovações ecológicas, voltadas ao processo de desenvolvimento de produtos e processos de manufatura.

Rohrich e Cunha (2004) ressaltam que as inovações tecnológicas de produtos e processos, e, por conseguinte, a geração de redução de custos ou incremento na valorização dos produtos, podem variar de acordo com a importância atribuída à gestão ambiental. Dessa forma, infere-se, neste contexto, que quanto maior for a preocupação empresarial com a gestão ambiental, maior será o número de inovações orientadas para produtos e processos ambientalmente adequados.

A internalização adequada da variável ambiental pelas empresas, pode propiciar a utilização de insumos tais como energia, matérias-primas, e trabalho de modo mais produtivo, potencializando reduções em custos, bem como a compensação dos gastos com melhorias ambientais (OLIVEIRA, BORGES e JABBOUR, 2005); idéia corroborada por Lustosa (2004), que sinaliza que a preservação ambiental está associada ao aumento da produtividade dos recursos utilizados na produção e, conseqüentemente, a possíveis incrementos da competitividade empresarial.

\subsubsection{Concepções diferentes}

A corrente de pensamento "liderada" por Porter e Linde (1995 e 1999) e Shrivastava (1995) foi convencionalmente chamada de corrente ganha-ganha (win-win), na qual a premissa básica seria a de que a tendência a regulamentações mais "estreitas" e adequadas poderia gerar inovações por parte das empresas, que por sua vez reduziriam custos, diferenciariam produtos e melhorariam a imagem frente a sociedade (aumentando o potencial competitivo), tendo em contrapartida os ganhos sociais decorrentes da proteção do meio ambiente. 
Alguns autores, contrariando esta corrente, discordam e questionam a generalização dos benefícios acima citados (WALLEY e WHITEHEAD, 1994; PALMER, OATES e PORTNEY, 1995; MAXWELL, 1996; REINHARDT, 1999).

Palmer, Oates e Portney (1995) discutem a validade e a generalidade da hipótese levantada por Porter e Linde, a qual defende regulamentações adequadas como meio fomentador de melhorias para as empresas e para o meio ambiente. Os autores ressaltam que seria necessário comparar os efeitos benéficos que as regulamentações induzem com os custos que tem de se arcar para que sejam alcançados tais benefícios. A premissa de que regulamentações mais severas induzem as empresas a uma melhoria na competitividade, principalmente através do corte de custos e aumento da lucratividade, pode não ser totalmente válida, sendo adequado um estudo mais aprofundado dos fatores circundantes.

Neste sentido, a abordagem que ressalta a relação custo-benefício (tradicional) destaca a existência de um trade-off entre regulamentação ambiental e competitividade, chamada por Porter e Linde (1995 e 1999) de visão estática.

Maxwell (1996) defende a idéia de que a proposição de regulamentações ambientais é de internalizar dos custos de poluição, que tradicionalmente recaem sobre a sociedade. $\mathrm{O}$ autor argumenta que esta idéia é no mínimo incoerente no que tange aos ganhos em competitividade, uma vez que, se as regulamentações levam a internalização dos custos pelas empresas, não podem por outro lado aumentar a lucratividade.

Ainda nesta linha, o mesmo segue argüindo que a regulamentação cria ganhadores e perdedores. Firmas que têm vantagem competitiva advinda dos marcos regulatórios podem realmente defender a idéia que tais regras podem ser lucrativas. Contudo, estes lucros tendem a surgir à medida que os competidores são enfraquecidos pelas regulamentações, chegando, em alguns casos, a deixar o mercado em que atuam. Nestes casos, os lucros crescem indiretamente pelas mudanças na estrutura competitiva, do que diretamente pela premissa de redução de custos. 
Reinhardt (1999) argumenta que alguns pontos que ligam microeconomia e política ambiental precisam ser destacados. Primeiramente, entre outros aspectos da estratégia corporativa, a política ambiental precisar estar baseada nos fundamentos econômicos do negócio (a estrutura da indústria na qual a empresa opera, sua posição e suas capacidades). Para o autor, não há uma fórmula que serve para todas as empresas.

Neste contexto, o autor prossegue observando que muitos outros autores defendem a idéia de que algumas firmas podem se beneficiar de uma mudança para um ciclo fechado de produção, o que não se consolida como verdade, segundo ele. A mesma negativa se aplica a algumas diversas políticas, tais como: a diferenciação de produtos, o uso da regulamentação ambiental para aumentar os custos dos concorrentes e o provimento voluntário de bens públicos (bens ambientais). Algumas empresas podem estar aptas ou não para implementar tais políticas, podendo, em alguns casos, se transformar em riscos para o negócio. 


\section{A economia e o desenvolvimento sustentável}

O conceito de desenvolvimento sustentável é um termo normativo, segundo Romeiro (2004), que surgiu com o nome de eco-desenvolvimento no início da década de 1970, com autoria de Ignacy Sachs. Tal conceito surgira num contexto de controvérsia sobre as relações entre crescimento econômico e meio ambiente, amplamente divulgadas pela publicação do relatório do Clube de Roma (Limites do Crescimento) que pregava crescimento zero como forma de evitar a catástrofe ambiental.

Para Pearce e Atkinson (1998), poucos conceitos parecem ter capturado o imaginário público quanto o de desenvolvimento sustentável, abraçando a idéia de garantir que as futuras gerações herdem um planeta que terá as mesmas condições que as gerações presentes estão tendo para se sustentar. Os autores prosseguem argumentando que, em termos econômicos, o desenvolvimento sustentável veio a ser comparado a uma linha de desenvolvimento que assegura um bem-estar per capita por um determinado horizonte de tempo.

Muitas definições surgiram acerca da relação entre meio ambiente e desenvolvimento, porém a mais célebre formulação do conceito é a que foi publicada no relatório Nosso Futuro Comum, no ano de 1987 (apresentado no capítulo 1) (TURNER, 1992; HEDIGER, 1999).

Ao longo do tempo, e apesar da larga aceitação do conceito, algumas divergências quanto a sua interpretação não foram devidamente sanadas, devendo-se essas basicamente ao caráter normativo do termo (ROMEIRO, 2004).

As dificuldades para o abrandamento das divergências não se deram apenas à variabilidade de definições, como também às diferenças no tocante às díspares interpretações. 
No debate acadêmico em economia do meio ambiente, as versões sobre o conceito dividem-se em duas correntes principais de interpretação (TURNER, 1992; CABEZA-GUTÉS, 1996; PEARCE e ATKINSON, 1998; AYRES, BERGH e GOWDY, 1998):

1. A primeira corrente é representada principalmente pela chamada economia ambiental (o mainstrean neoclássico), sendo a sua concepção de sustentabilidade assinalada na literatura por "sustentabilidade fraca" (weak sustainability).

2. A segunda corrente de interpretação é representada principalmente pela chamada economia ecológica, sendo a visão dessa, de sustentabilidade, conhecida na literatura como "sustentabilidade forte" (strong sustainability).

Nas seções a seguir discutir-se-ão os aspectos teóricos destas definições.

\subsection{O capital natural à luz da economia}

Antes de discutir as concepções adotadas pelas vertentes econômicas acerca da sustentabilidade, torna-se necessária uma breve revisão dos conceitos de capital, bem como da definição do que se depreende que seja capital natural.

A concepção de capital, originária da ciência econômica, não difere-se muito entre os autores. Constanza et al. (1998) refere-se a capital como o estoque de matéria ou informação disponível em dado momento do tempo e que o uso, individualmente ou em grupo, potencializa um fluxo de serviços que pode ser empregado na transformação de materiais que aumentam o bemestar da sociedade.

Hawken, Lovins e Lovins (1999, p. 3), em sua famosa obra Capitalismo Natural, acentuam que a economia requer quatro tipos de capital para seu funcionamento adequado:

1. Capital humano: na forma de trabalho e inteligência, cultura e organização; 
2. Capital financeiro: consiste em dinheiro, investimentos e instrumentos monetários;

3. Capital manufaturado: infra-estrutura, as máquinas, as ferramentas e as fábricas, entre outros e;

4. Capital natural: constituído de recursos naturais, sistemas vivos e serviços do ecossistema.

Os autores prosseguem observando que o sistema industrial utiliza as três primeiras formas de capital para transformar o capital natural no material de nossa vida cotidiana.

Constanza et. al (1998) apresenta um desenvolvimento teórico parecido, observando que o "estoque de capital" de uma sociedade compreende: capital natural (florestas, minerais, atmosfera, etc.); capital manufaturado ou manmade capital (máquinas, estradas, etc.) e; capital humano dos corpos físicos, sendo que o fluxo de serviços provenientes do uso do capital pode ou não deixar seu estoque intacto - ponto-chave da discussão teórica posterior.

Já Denardin e Sulzbach (2001), em seu trabalho, desenvolvem conceitualmente quatro tipos de capital: natural, cultural, manufaturado e cultivado. Com relação ao capital natural, os autores ressaltam a idéia de que o capital natural e o capital produzido pelo homem (manufaturado) são complementares e não substitutos, como trata a economia ecológica e o caráter híbrido do conceito que, segundo os autores, seria formado a partir da economia e da ecologia, ressalta a importância da qualidade ambiental como pré-condição para o bem-estar da sociedade humana e sua sustentabiidade (econômica) a longo prazo.

Para Mac Donald et al. (1999), o capital natural é constituído de nosso ambiente natural, ou seja, é o estoque de recursos naturais ou ativos ambientais existentes (por exemplo, florestas e terras agricultáveis), que produzem um fluxo de bens e serviços úteis à humanidade, fornecendo toda espécie de funções ambientais.

Desta forma, o capital natural possui características que dispertam interesses econômicos, sociais e ambientais, uma vez que disponibiliza bens e 
serviços ecossistêmicos essenciais para a sobrevivência das espécies humana e não-humana.

\section{Estoque total de capital}

Definição de Hawken, Lovins e Lovins, (1999)

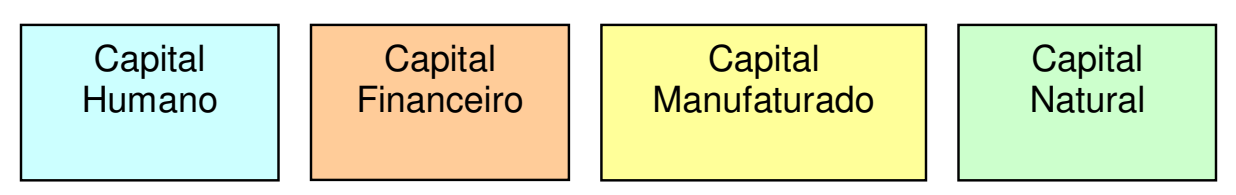

\section{Definição de Constanza et al. (1998)}
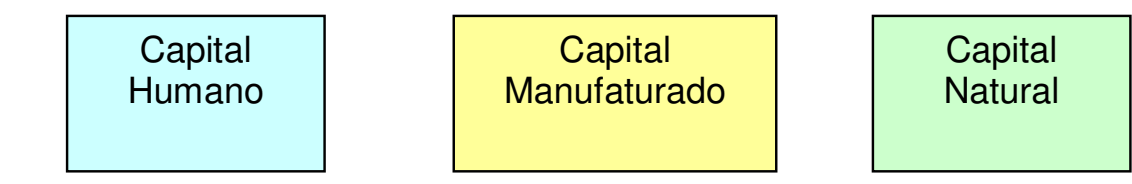

\section{Definição de Denardin e Sulzbach (1999)}

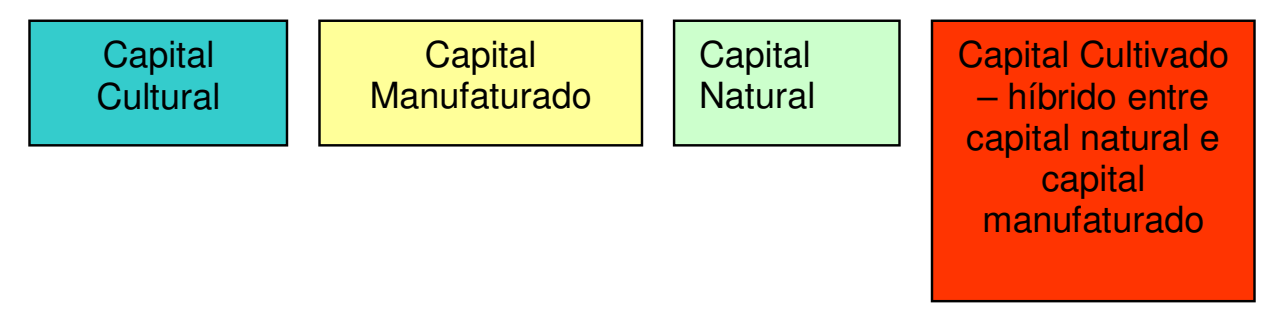

Figura 4 - As diferentes formas de capital

\subsection{A sustentabilidade fraca}

A corrente representada pela economia ambiental (vertente do mainstrean neoclássico) considera que os recursos naturais (como fonte de insumos e como capacidade de assimilação de impactos dos ecossistemas) não representam, a longo prazo, um limite absoluto à expansão da economia (ROMEIRO, 2004, p.7).

Nos primórdios, estes recursos nem mesmo apareciam nas representações analíticas da realidade econômica, como por exemplo na especificação da função de produção, na qual estavam apenas o capital e o trabalho (a economia funcionava "sem" recursos naturais). Tal visão implícita 
de infinitude de recursos naturais na análise neoclássica foi objeto de crítica sistemática.

\footnotetext{
"a perspectiva econômica neoclássica identifica o uso ineficiente dos recursos naturais como a principal razão para os problemas ambientais. Tal eficiência é causada por falhas de mercado ou efeitos externos. Neste contexto, a estratégia econômica de análise está focada em precificar adequadamente os bens ambientais (RENNINGS e WIGGERING, 1997, p. 26)."
}

Com o tempo, os recursos naturais passaram a ser incluídos nas representações de função de produção, mas mantendo a sua forma multiplicativa, que significa a substitubilidade perfeita entre capital, trabalho e recursos naturais $(Y=f\{K, L, R\})$ e, portanto, a suposição de que os limites impostos pela disponibilidade de recursos naturais podem ser indefinidamente superados pelo progresso técnico que os substitui por capital (ou trabalho) (AYRES, BERGH e GOWDY, 1998; ROMEIRO, 2004).

Pearce e Atkinson (1998) observam que para esta vertente, uma economia é considerada não-sustentável se a poupança total fica abaixo da depreciação acumulada dos ativos produzidos ou não-produzidos, sendo estes últimos usualmente restritos a recursos naturais. Desta forma, a idéia subjacente é a de que o investimento compensa as gerações futuras pelas perdas de ativos causadas pelo consumo e produção correntes.

O sistema econômico é visto, segundo Romeiro (2004), como suficientemente grande para que a disponibilidade de recursos naturais se torne uma restrição a sua expansão, mas apenas uma restrição relativa, superada indefinidamente pelo progresso científico e tecnológico. 


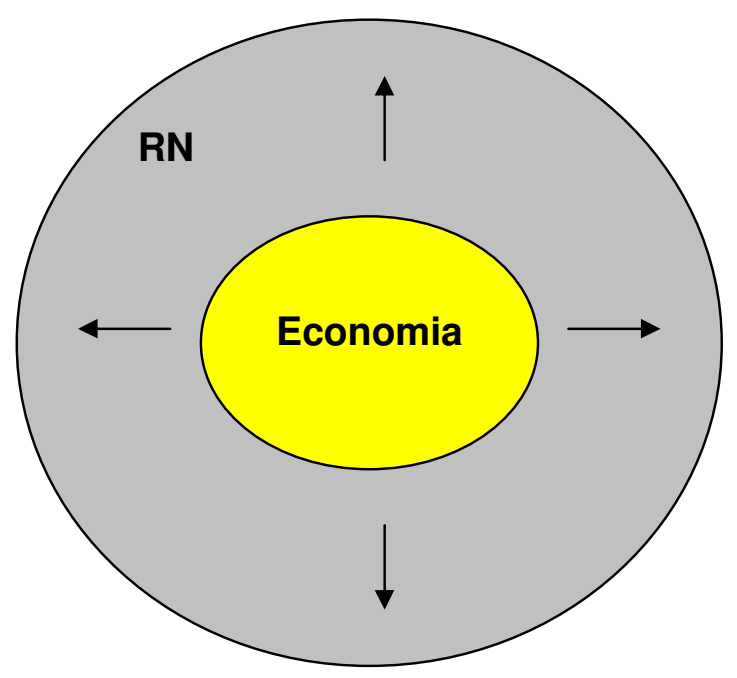

Figura 5 - 0 sistema econômico pela sustentabilidade fraca Adaptado de Romeiro (2004)

A figura 5 demonstra a idéia de que, na concepção de sustentabilidade fraca, tudo se passa como se o sistema econômico fosse capaz de se mover suavemente de uma base de recursos para outra, à medida que cada uma é esgotada; o progresso científico e tecnológico é, assim, a variável-chave para garantir que esse processo de substituição não limite o crescimento econômico no longo prazo (PEARCE e ATKINSON, 1998; ROMEIRO, 2004).

Para Romeiro (2004), a idéia subjacente, neste contexto, é a de que o investimento e os avanços tecnológicos compensam as gerações futuras pelas perdas de ativos (naturais) causadas pelas atividades de consumo de produção correntes.

Para Pearce e Atkinson (1998) e Ayres, Bergh e Gowdy (1998), a sustentabilidade fraca, implicitamente, assume que as poupanças são investidas em capital manufaturado ou capital humano, que posteriormente são perfeitamente substituíveis por capital natural. Desta forma, países com um histórico de escassez de recursos e danos em ecossistemas podem parecer sustentáveis, uma vez que invistam suas poupanças nas duas formas de capital anteriormente citadas.

Alguns autores, como Pearce e Atkinson (1998), Cabeza-Gutés (1996) e Romeiro (2004), apontam que esta abordagem tem sido criticada tanto em 
termos de hipóteses assumidas (crítica externa) quanto em termos de sua inconsistência metodológica (crítica interna).

Primeiramente assinala-se a impossibilidade de o capital produzido pelo homem substituir os serviços essenciais fornecidos por algumas categorias de recursos naturais. Neste sentido, não há o reconhecimento das características únicas que certos recursos naturais possuem, ocasionando o fato de estes não poderem ser simplesmente substituídos pela ação humana.

No que concerne à inconsistência metodológica, Ayres, Bergh e Gowdy (1998) e Romeiro (2004) ressaltam que esta ficaria patente no quesito valoração do capital, uma vez que a sustentabilidade fraca propõe uma agregação combinando capital produzido e natural, requerendo um numerário comum, uma função atribuída ao sistema de preços correntes. Para serem valorados, os recursos naturais deveriam se referir aos preços existentes (o capital produzido é estimado pelos preços de mercado observados).

Argumenta-se que o numerário não deveria basear-se no sistema de preços vigentes porque esse não capta inúmeros aspectos ambientais, causando o problema motivador da valoração dos recursos naturais. Um sistema de preços apropriado deveria considerar como cada bem seria afetado se todas as funções ambientais fossem monetizadas, porém as funções ambientais só podem ser monetizadas uma vez que o sistema de preços for conhecido. Esse problema de circularidade tornaria o uso de preços de mercado um procedimento bastante questionável para determinar se uma economia é ou não sustentável (ROMEIRO, 2004).

Pearce e Atkinson (1998) destacam que para essa corrente, os mecanismos pelos quais se dá a ampliação indefinida dos limites ambientais ao crescimento econômico devem ser principalmente os mecanismos de mercado. No caso dos bens ambientais transacionados no mercado (insumos, materiais e energéticos), a escassez crescente de um determinado bem se traduziria facilmente na elevação de seu preço, o que, por sua vez, induziria à introdução de inovações que permitissem poupá-lo, substituindo-o por outro recurso mais abundante (ROMEIRO, 2004). 
Em se tratando de serviços ambientais, em geral não transacionados no mercado por sua natureza de bens públicos (ar, água, ciclos bioquímicos globais de sustentação da vida, capacidade de assimilação de rejeitos, etc.), Pearce e Atkinson (1998), Ayres, Bergh e Gowdy (1998) e Romeiro (2004) concordam que o mecanismo de mercado, descrito anteriormente, falha. Para corrigir tal falha, Romeiro (2004) argumenta que seria necessário intervir para que a disposição a pagar por esses serviços ambientais possa se expressar à medida que sua escassez aumenta.

Desta forma, torna-se necessário observar a evolução natural das preferências dos indivíduos em função do próprio processo de crescimento econômico, que na acepção desta corrente, ocorre no sentido de uma menor tolerância a uma escassez crescente dos serviços devido à poluição. A explicação para este fato, segundo Ayres, Bergh e Gowdy (1998) e Romeiro (2004), estaria em que, nos estágios iniciais de desenvolvimento econômico, a crescente degradação do meio ambiente é aceita como um efeito colateral ruim, mas inevitável; entretanto, a partir de certo nível de bem-estar econômico, a população torna-se mais sensível e disposta a pagar pela melhoria da qualidade do meio ambiente, o que, por sua vez, induziria à introdução de inovações institucionais e organizacionais necessárias para corrigir as falhas de mercado decorrentes do caráter público da maior parte dos serviços ambientais.

Romeiro (2004) destaca que as soluções ideais, pontuadas na literatura, seriam aquelas que, de algum modo, criassem as condições ideais para o livre funcionamento dos mecanismos de mercado, seja diretamente, eliminando o caráter público de tais bens e serviços (pela definição de direitos de propriedade sobre estes); seja indiretamente, pela valoração econômica dos bens e da imposição desses valores pelo Estado através de taxas.

A primeira solução apontada acima esbarraria no fato decorrente que seria a privatização de recursos como água, ar, entre outros, o que sofreria objeções pelo elevado custo de transação decorrente de processos de barganha que envolveriam, nestes casos, centenas ou menos milhares de agentes. 
Na segunda solução, a pressuposição baseia-se na possibilidade de se calcular os valores dos bens a partir de uma curva marginal de degradação ambiental. Cria-se, assim, para cada agente econômico, um trade off entre seus custos (marginais) de controle de poluição e os custos (marginais) dos impactos ambientais (externalidades) provocados por suas atividades produtivas. O agente econômico seria forçado a "internalizar" tais impactos através de taxações, procurando minimizar seu custo total, resultado da soma do quanto se gasta para controlar a poluição (custos de controle) com a quantia a ser gasta com o pagamento de taxas por poluir (custo de degradação). $\mathrm{O}$ ponto de equilíbrio é chamado de poluição ótima (Figura 6).

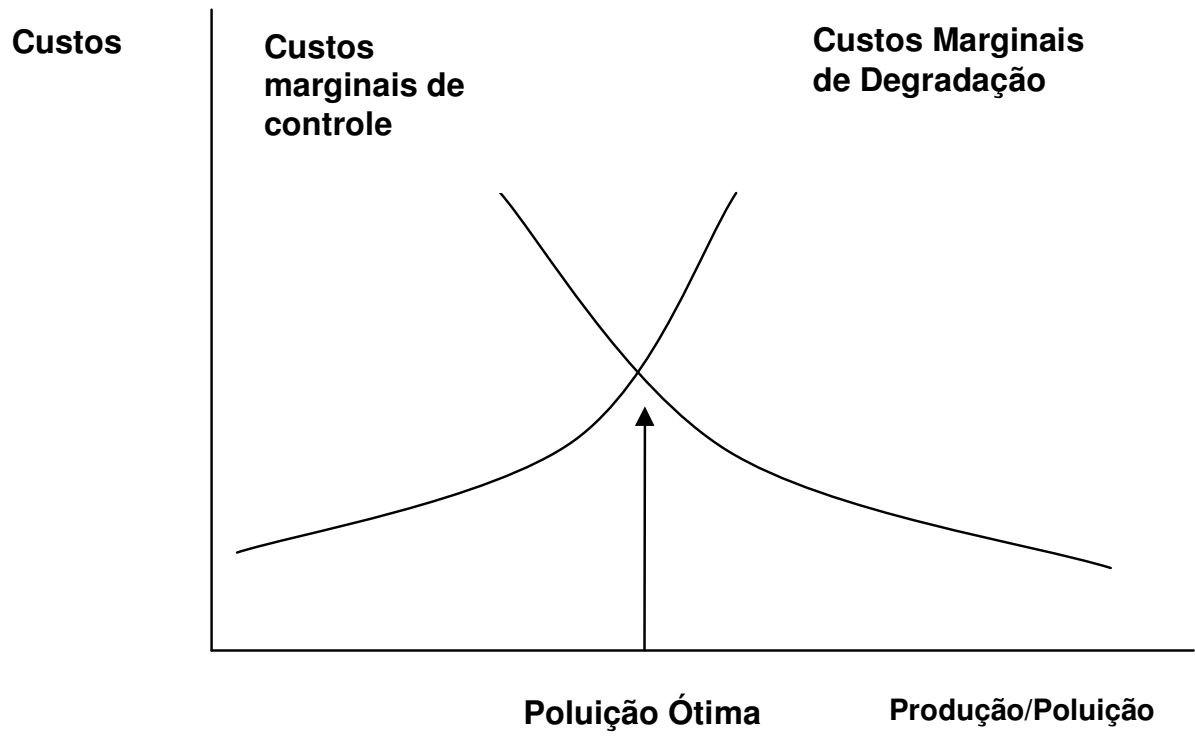

Figura 6 - 0 nível de poluição ótima Fonte: Romeiro (2004)

Há o reconhecimento de que o cenário apresentado na figura acima enquadra-se num âmbito fictício, uma vez que apresenta uma curva suave de custos marginais de degradação, ignorando o fato de que os impactos ambientais evoluem de modo imprevisível devido à existência de efeitos sinérgicos e de reações defasadas (DASGUPTA e MÄLER, 1995, p. 2378).

Contudo, segundo Romeiro (2004), permanece o princípio de que a política ambiental mais eficiente é aquela que cria as condições, através da 
precificação, para que os agentes econômicos "internalizem" os custos da degradação que provocam.

\subsection{A sustentabilidade forte}

"[...] a estratégia ecológica analisa os impactos das atividades econômicas nos ecossistemas. Esta estratégia tem por objetivo manter os ecossistemas intactos, protegendo as funções naturais como a estabilidade ecológica ou resiliência ecológica [...] (RENNINGS e WIGGERING, 1997, p. 26)."

O contexto interpretativo do conceito de sustentabilidade pela teoria econômica traz uma segunda corrente, representada principalmente pela chamada economia ecológica, que enxerga o sistema econômico como um subsistema de um todo maior que o contém, impondo uma restrição absoluta à sua expansão, como apresentado na figura 5 (ROMEIRO, 2004, p. 11). Bergh, Ayres e Gowdy (200x) observam que a sustentabilidade é vista como "oportunidades" de vida não-decrescentes ao longo do tempo, devendo esta situação ser atingida através da conservação do estoque de capital humano, capacidades tecnológicas, recursos naturais e qualidade ambiental.

Neste contexto, o capital manufaturado (man-made capital) e o capital natural são essencialmente complementares (DENARDIN e SULZBACH, 2001). Na literatura, esta visão é referida através do conceito de sustentabilidade forte (strong sustainability).

Reconhece-se que os recursos naturais são "inputs" essenciais na produção econômica, consumo ou bem-estar, e que não podem ser simplesmente substituídos por outros tipos de capital (BERGH, AYRES e GOWDY, 1998, p. 4).

A sustentabilidade forte considera o capital natural como provedor de algumas funções que não são substituíveis por capital "manufaturado". Essas funções, também chamadas de capital natural crítico, são acentuadas pela definição de sustentabilidade, que visa garantir que as gerações futuras desfrutem de um estoque de capital natural similar ao que a presente geração usufrui. Desta forma, a sustentabilidade é vista em termos de capital natural não-declinante ao longo do tempo (CABEZA-GUTÉS, 1996). 


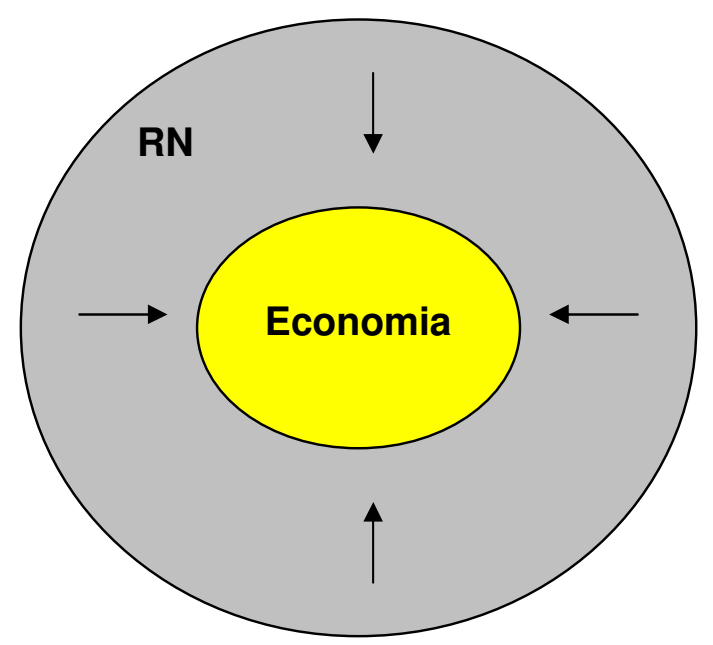

Figura 7 - 0 sistema econômico pela sustentabilidade forte Adaptado de Romeiro (2004)

O progresso científico e tecnológico é visto como um dos fatores fundamentais para aumentar a eficiência na utilização dos recursos naturais em geral (renováveis e não-renováveis). Nesse aspecto, essa corrente partilha com a anterior a convicção de que é possível instituir uma estrutura regulatória baseada em incentivos econômicos que sejam capazes de induzir a internalização das questões, como também 0 aumento significativo da eficiência na utilização dos recursos (TURNER, 1992; HEDIGER, 1999; AYRES, BERGH e GOWDY, 1998; ROMEIRO, 2004).

A discordância fundamental entre as duas correntes supra-citadas permanece no ponto relacionado à capacidade de superação indefinida dos limites ambientais globais (DENARDIN e SULZBACH, 1999; ROMEIRO, 2004).

Conforme Turner et al. (1994, p. 57-58) são levados em consideração, na concepção de sustentabilidade forte, fatores sócio-econômicos e ambientais que podem ser elencados nos seguintes termos:

- presença de incertezas quanto ao funcionamento e ao valor do serviço total dos ecossistemas;

- presença de irreversibilidades: algumas decisões podem resultar em mudanças que são fisicamente impossíveis de serem revertidas ou restringidas em termos de custos;

- a não substitubilidade de certos componentes do capital natural. 
Romeiro (2004, p. 11) observa que, de certo modo, na concepção desta vertente, a sustentabilidade do sistema econômico no longo prazo não é possível sem a estabilização dos níveis correntes de consumo per capita de acordo com a capacidade de carga do planeta. Neste sentido, caberia à sociedade como um todo, seja através do Estado ou outra forma de organização coletiva, decidir sobre o uso desses recursos de modo a evitar perdas irreversíveis, potencialmente catastróficas.

Desta forma, o capital natural crítico seria analisado pelo trabalho científico interdisciplinar, levando em conta tanto os fatores ecológicos (capacidade de carga) como também os sócio-econômicos (como por exemplo, a definição de padrões mínimos de segurança) (TURNER et al., 1994; ROMEIRO, 2004).

O ponto-chave, neste âmbito de análise da relação entre desenvolvimento econômico e meio ambiente, está no modo de operacionalizar o sistema econômico, com a consideração da existência de limites que podem restringir o seu funcionamento.

O mecanismo proposto pela vertente neoclássica, por definição, desconsidera a existência de tais limites, segundo Romeiro (2004, p. 12), supondo a possibilidade de substituição indiscriminada dos recursos naturais que se tornam escassos por recursos abundantes, através de soluções inovadoras.

Hawken, Lovins e Lovis (1999), Denardin e Sulzbach (2001) e Romeiro (2004) observam que, no caso dos bens transacionados no mercado, tais como insumos materiais e energéticos, o esquema neoclássico convencional (sustentabilidade fraca) pressupõe que a escassez crescente de um determinado bem eleva seu preço. Esta elevação induziria à introdução de inovações que permitiriam poupá-lo, podendo substituí-lo por outros recursos mais abundantes cujos estoques os agentes econômicos "supostamente" conhecem de antemão, juntamente com o conhecimento das diferenças de qualidade, do curso futuro do progresso tecnológico e da própria demanda. A economia ecológica, por sua vez, destaca que os preços refletem a disponibilidade de cada recurso independentemente do estoque total desses, 
impedindo que possam servir para sinalizar um processo de extração ótima do ponto de vista da sustentabilidade.

Em se tratando dos serviços ambientais fornecidos pelo capital natural (e não transacionados no mercado pela sua natureza de bens públicos), o mecanismo de ajuste convencional não leva em conta os princípios ecológicos fundamentais para garantir a sustentabilidade, na medida em que este é baseado no cálculo de custo e benefício feito pelos agentes econômicos visando a alocação de recursos entre investimentos em controle de poluição e pagamentos de taxas por poluir de modo a minimizar o custo total (TURNER et al., 1994; ROMEIRO, 2004). Desta forma, o equilíbrio encontrado como "poluição ótima" estaria voltado para a concepção de equilíbrio econômico e não ecológico, pois, ecologicamente, não se pode falar em equilíbrio quando a capacidade de assimilação do meio é ultrapassada, como demonstrado no modelo, uma vez que a poluição permanece.

A premissa assumida neste caso, segundo Turner et al. (1994) e Perk et al. (1998), Bergh, Ayres e Gowdy (1998) e Romeiro (2004), na qual a capacidade de assimilação do meio estaria sendo ultrapassada em um dado período (t), potencializaria a redução da capacidade de assimilação do meio no período seguinte $(t+1)$ e assim sucessivamente. $O$ resultado pode ser uma perda irreversível, que, por sua vez, pode acarretar uma "degradação líquida", sendo que somente suas conseqüências de segunda ordem são levadas em conta, isto é, aquelas que afetariam o nível de bem-estar dos agentes no curto prazo.

A proposição neoclássica implica que a tecnologia e as preferências são tomadas como parâmetros não-físicos que determinam uma posição de equilíbrio na qual se ajustam as variáveis físicas das quantidades de bens e serviços ambientais utilizados (a escala). O correto, pregado pela economia ecológica, seria exatamente o oposto, tomar essas quantidades como os parâmetros físicos aos quais deveriam se ajustar as variáveis não-físicas da tecnologia e das preferências (RENNINGS e WIGGERING, 1997; BERGH, AYRES e GOWDY, 1998; ROMEIRO, 2004).

Romeiro (2004, p. 13) ressalta que estes parâmetros de sustentabilidade poderiam apenas ser definidos socialmente. O autor desenvolve esta idéia 
observando que a determinação de uma escala sustentável, da mesma forma que uma distribuição justa de renda, envolve valores outros além da busca individual de maximização dos ganhos ou do bem-estar, valores esses que têm de se afirmar num contexto de controversas e incertezas científicas decorrentes da complexidade dos problemas ambientais globais.

Denardin e Sulzbach (2001) afirma que para esta escola, os limites ao crescimento são reais e acarretados pela escassez de recursos naturais e capacidade de suporte do meio, sendo pouco provável que somente a introdução de soluções advindas de inovações tecnológicas possam superar as restrições encontradas.

Neste contexto, Romeiro (2004) destaca que a determinação de valores ótimos, escalas sustentáveis de utilização do capital natural, entre outros fatores do desenvolvimento sustentável, só poderiam se concretizar através de processos coletivos de tomada de decisões.

De uma forma geral, a literatura pertinente enfatiza que a economia ecológica trata, na sua concepção de sustentabilidade, de realçar em primeiro lugar a capacidade de suporte do planeta e em segundo plano a distribuição eqüitativa dos recursos (tema desprezado pela teoria neoclássica).

Para a economia ecológica, cedo ou tarde, o uso do meio ambiente como fonte de recursos e escoadouro de dejetos terá de ser reavaliado; a escala da atividade econômica terá de ser repensada no intuito de não explorar os recursos naturais acima de sua capacidade de regeneração e não emitir resíduos acima de sua capacidade de assimilação (DENARDIN e SULZBACH, 2001).

Para que a escala econômica continue crescendo às custas de um estoque de capital natural que, ao contrário, está diminuindo, faz-se necessário investir em capital natural. Porém, como a capacidade humana de recriar capital natural é bastante limitada, tais investimentos teriam de ser indiretos, ou seja, seria preciso conservar o capital natural existente, expandir o capital natural cultivado, aumentar a eficiência e racionalizar o uso dos recursos naturais. Para tal intento, seria necessário um processo de conscientização 
generalizado entre os agentes econômicos, envolvendo governos, empresas e sociedade civil, acerca das questões ambientais .

Nesta linha teórica, a obra de Hawken, Lovins e Lovins (1999) foi desenvolvida, e traz algumas considerações sobre questões relacionadas à sustentabilidade. Primeiramente, os autores fazem menção ao abrupto declínio que o capital natural está sofrendo, chegando à afirmação de que o status quo do capitalismo, que vem sendo praticado, seria uma "aberração" lucrativa e insustentável do desenvolvimento humano.

Esta obra ainda traz a observação de que o capitalismo industrial não se ajusta cabalmente a seus próprios princípios, uma vez que liquida seu capital (natural) e convenciona isso como renda. 


\section{Estudo de Caso}

Para a realização do presente trabalho, optou-se por limitar o escopo de estudo a uma organização específica. A justificativa para tal escolha está no objetivo da obtenção de profundidade de uma análise. Os fatos foram observados em seu ambiente natural, dentro de um período limitado, conforme estratégia definida para um estudo de caso.

Segundo Godoy (1995, p. 25), um estudo de caso visa ao exame detalhado de um ambiente, de um sujeito ou de uma situação particular. Yin (2005) ressalta que tal estratégia de pesquisa é amplamente utilizada em estudos organizacionais, com vistas a elucidar como e por que certos fenômenos contemporâneos inseridos em algum contexto da vida real ocorrem.

O estudo de caso representa uma forma específica de coleta e análise de provas empíricas. As fontes de evidência utilizadas foram: observação direta, a realização de uma entrevista estruturada, análise de materiais institucionais.

O processo de análise de dados levado a cabo nesta pesquisa, leva em consideração uma contínua interação com a teoria, buscando corroborar a consistência do quadro teórico exposto nos capítulos precedentes.

\subsection{Critérios para a escolha da organização: objeto do estudo de caso}

Diante de uma análise acerca do posicionamento em relação às questões voltadas para a gestão ambiental empresarial, optou-se pela escolha de uma organização que possuísse comportamento diferenciado dentro deste espectro de análise.

A empresa analisada possui características peculiares, haja visto, não apenas as certificações obtidas, como também pelos programas desenvolvidos 
e a preocupação na difusão das informações voltadas à preservação do meio ambiente.

\subsection{O processo de coleta de dados e informações}

Para o processo de coleta de dados e informações pertinentes à pesquisa, levou-se a cabo uma série de procedimentos. Num primeiro momento, foram escolhidos alguns pontos centrais a serem observados na empresa estudada; posteriormente, esses foram compilados num roteiro utilizado durante algumas entrevistas agendadas.

As entrevistas foram realizadas com o gerente responsável pelas atribuições relativas à gestão ambiental na planta estudada. Após a realização das entrevistas, foram feitas também algumas visitas técnicas, com o intuito de se averiguar concretamente os pontos questionados.

\subsection{Apresentação da empresa X}

A empresa X, fundada em meados da década de 1930, atua no ramo de produção de materiais escolares e cosméticos. Suas plantas e florestas estão localizadas em alguns dos principais estados brasileiros. A empresa estudada pode ser considerada um player importante do setor, em termos nacionais e internacionais.

O acesso às informações requeridas para o presente trabalho ocorreu em duas plantas situadas na mesma região metropolitana, gerenciadas pelo mesmo responsável técnico. Essas plantas estão integradas a mais duas outras (uma delas administrativa), todas devidamente certificadas pela ISO 14.001. Duas de suas plantas possuem unidades florestais que possuem 0 certificado FSC (Forest Stewardship Counci). Apenas uma planta, que ainda não está integrada às demais, não possui certificação.

Cabe ressaltar, que o presente trabalho tem como foco principal as atividades realizadas nas plantas industriais, não estendendo a profundidade de análise para a área florestal. 


\subsection{Apresentação dos dados e informações}

Conforme observado nas seções precedentes, a coleta dos dados foi realizada durante as entrevistas e visitas técnicas realizadas, respeitando um roteiro pré-definido de questões levantadas (vide anexo).

De modo geral, as questões podem ser agrupadas em dois "macro" blocos:

1 - Questões que abordam o modo como a variável ambiental vem sendo tratada/incorporada pela organização;

2 - Orientações específicas que visam analisar os possíveis desdobramentos organizacionais decorrentes da adoção de práticas de gestão ambiental.

\subsubsection{A variável ambiental e a organização}

De acordo com as informações obtidas, o tratamento das questões ambientais pela empresa não é fato recente e data de algumas décadas, porém, foi em meados da década de 1990 que, iniciou-se um processo sistemático de tratamento das questões ambientais em âmbito administrativo.

Como ponto de partida, a organização preocupava-se primordialmente em atender às legislações ambientais até então vigentes; tinha-se nas pesadas multas passíveis de serem aplicadas, um fator preponderante na consideração e na abordagem do meio ambiente pela empresa. Isto significava adequar-se minimamente sem o dispêndio de grandes volumes de capital.

Contudo, os processos produtivos sempre foram dependentes do meio natural para a obtenção de insumos produtivos, bem como para o depósito dos resíduos gerados pela produção. Desta forma, o meio ambiente passa a ser visto como fator significativo em todo o processo e, o desafio, era como produzir e ao mesmo tempo mitigar os impactos ambientais.

Neste contexto, surgem como dois pontos-chave os resíduos e os efluentes; elementos gerados na atividade produtiva, nocivos ao meio ambiente quando depositados acima de determinados limites - o que convencionou-se chamar de passivos ambientais. 
Outro catalisador deste processo, que apresenta-se de modo velado, é o direcionamento adotado pela matriz internacional na qual os procedimentos sustentáveis já estavam estabelecidos, adequados e certificados.

No final da década, mais especificamente no ano de 1999, houve a criação de um Sistema de Gestão Ambiental (SGA) próprio e informal, concomitantemente à criação de uma Estação de Tratamento de Resíduos (ETR).

Os primeiros resultados advindos destas medidas mostraram-se satisfatórios, ocasionando discussões acerca da estruturação de um SGA próprio, que viria a se consumar no ano de 2001. Para o estabelecimento do sistema, foi contratada uma consultoria especializada, visando a adequação às normas ISO 14.001, bem como a realização de treinamentos e o estabelecimento de procedimentos específicos.

No ano seguinte, seguiu-se, num processo natural, a certificação em primeira instância, sendo as plantas analisadas, devidamente auditadas por órgãos competentes.

Os principais desdobramentos organizacionais posteriores ao processo apresentado anteriormente serão apresentados na próxima seção.

Neste contexto, desenvolveu e estabeleceu-se uma política ambiental que contempla: compromissos permanentes da empresa com o meio ambiente, que visam superar as exigências da legislação pertinente.

\subsubsection{Orientações Específicas}

Como resultado natural do processo de adequação aos procedimentos estabelecidos no SGA, seguiu-se a criação de um departamento específico para o tratamento das questões relacionadas à gestão ambiental.

Este departamento cuida essencialmente da compilação, tratamento e análise dos dados relevantes ao SGA adotado. É responsável também pelas adequações, fixação de metas e possíveis inovações que venham a obter efeitos positivos sobre o meio ambiente. 
O responsável técnico do departamento realiza periódicamente auditorias internas com o intuito de verificar possíveis falhas no atendimento e a identificação de oportunidades de melhorias ambientais.

Atualmente, o processo de verificação da conformidade ambiental dos bens produzidos inicia-se na fase de projeto, procurando obedecer a três pilares principais: qualidade, responsabilidade social e meio ambiente.

Apesar dos esforços empreendidos nos últimos anos, faz-se uma ressalva importante: a existência de barreiras ao estabelecimento das normas e procedimentos sustentáveis.

Muito embora o trabalho de divulgação e apresentação dos benefícios gerados por práticas sustentáveis sejam feitas constantemente, notou-se que a assimilação destas por parte de alguns elementos na organização ainda mostra-se lenta, tornando-se praticamente uma mudança de paradigma.

Através das informações obtidas, apreendeu-se que à medida que a sustentabilidade crescia como ponto corriqueiro na organização, observou-se aparente resistência por parte da função produtiva.

Nos dias atuais, os trabalhos voltados à educação corporativa, buscam incorporar constantemente os preceitos da gestão ambiental, no intuito de arraigar esses continuamente na cultura da organização.

A preocupação com processos sustentáveis contemplados no SGA adotado pela empresa $X$, levam em consideração também o comportamento dos fornecedores, bem como de alguns cientes que compram os resíduos sólidos gerados na produção para a fabricação de cimento. Estes agentes são consultados periodicamente pela empresa no tocante às suas certificações ambientais.

O quadro 4 apresenta um roteiro prático utilizado na coleta de algumas informações relevantes à pesquisa.

Nota-se que a empresa mantém um processo contínuo de monitoramento do desempenho ambiental, com a identificação de indicadores associados. A empresa consegue reciclar atualmente $65 \%$ dos resíduos gerados no processo produtivo, obtendo um ganho em eficiência significativo. 
Tal ganho em eficiência resulta em ganhos financeiros que girariam em torno de $68 \%$ sobre os investimentos no tratamento de resíduos.

O restante dos resíduos é comercializado com empresas de coprocessamento, para a fabricação de cimento.

\section{AS ETAPAS DA GESTAO DOS RESÍDUOS}

1 - O lixo produzido na fabrica é encaminhado para a ETR, onde o lixo reciclável é separado do lixo industrial

2 - Nesta fase é realizada a separação e o encaminhamento do lixo reciclável. Plástico, papéis, metais e madeira são vendidos para outras empresas para serem posteriormente reutilizados

3 - Tratamento do lixo industrial - esforços específicos.

Alguns itens componentes:

- plásticos que entram em contato com produtos químicos

- borra de tinta

- material sólido resultante do tratamento de água utilizada na fábrica

- óleo, combustíveis e solventes

- outros tipos de resíduos tais como restos de panos, e outros materiais utilizados para limpeza

\section{Quardo 3 - A gestão dos residuos}

A utilização de água e energia elétrica é outro ponto de impacto dentro do processo de gestão ambiental adotado pela empresa. Há grande preocupação com o tratamento e a re-utilização da água em circuito fechado, bem como a redução no consumo. No atual momento estão sendo realizadas pesquisas que viabilizem este processo que ainda não está plenamente estabilizado por questões de restrição financeira. A água tratada volta ao meio ambiente.

A empresa possui uma estação de tratamento de efluentes, onde $100 \%$ da água consumida no processo industrial e sanitário é tratada. Este dispositivo está plenamente adequado aos modelos adotados pela CETESB (Companhia de Tecnologia de Saneamento Ambiental).

Com relação à energia elétrica, a empresa tem como meta a redução contínua de seu dispêndio. Nos dois casos (água e energia) os indicadores mais fortes apresentam-se no confronto entre o total consumido versus o total produzido. As medidas tomadas no sentido de se reduzir o total consumido têm 
surtido efeito significativo nos ganhos em eficiência, acarretando importantes reduções de custos.

Outro ponto abordado pela empresa relaciona-se com a emissão de gases atmosféricos. Há uma caldeira que processa apenas material particulado e um lavador de gases; são realizadas auditorias periódicas para a verificação da emissão de gases contribuintes ao efeito estufa, bem como alguns solventes emitidos.

Esta preocupação é relativamente recente quando comparada a outros setores, por isso, talvez, a menos desenvolvida e a que demandaria mais estudos e melhorias.

Todos os aspectos apresentados anteriormente tendem a gerar devem estar adequados com preocupações preliminares, tais como estudos de adequação às normas e legislações específicas; estudos de impactos ambientais; departamento técnico destinado à estudos de melhorias; manutenção de uma brigada de emergência; treinamentos e capacitação constante; instrumentos eficazes de comunicação interna e externa; programas permanentes de educação ambiental. 


\begin{tabular}{|c|c|c|c|c|c|}
\hline \multirow[t]{2}{*}{ Atividades } & \multicolumn{2}{|c|}{$\begin{array}{l}\text { Realiza estas } \\
\text { atividades? }\end{array}$} & \multicolumn{2}{|c|}{$\begin{array}{l}\text { Estas atividades } \\
\text { possuem procedimentos } \\
\text { específicos? }\end{array}$} & \multirow[t]{2}{*}{$\begin{array}{l}\text { Detalhamento } \\
\text { das ações }\end{array}$} \\
\hline & Sim & Não & Sim & Não & \\
\hline $\begin{array}{l}\text { Monitoramento do } \\
\text { desempenho ambiental e } \\
\text { identificação de indicadores } \\
\text { associados }\end{array}$ & & & & & \\
\hline $\begin{array}{l}\text { Análise e adequação à } \\
\text { legislação ambiental e } \\
\text { códigos de práticas } \\
\text { setoriais }\end{array}$ & & & & & \\
\hline $\begin{array}{l}\text { Implantação de melhorias } \\
\text { tecnológicas }\end{array}$ & & & & & \\
\hline $\begin{array}{l}\text { Identificação contínua dos } \\
\text { aspectos ambientais }\end{array}$ & & & & & \\
\hline $\begin{array}{l}\text { Identificação dos impactos } \\
\text { ambientais }\end{array}$ & & & & & \\
\hline $\begin{array}{l}\text { Controle operacional das } \\
\text { atividades impactantes }\end{array}$ & & & & & \\
\hline $\begin{array}{l}\text { Controle e procedimentos } \\
\text { de comunicação }\end{array}$ & & & & & \\
\hline $\begin{array}{l}\text { Preparação e atendimento } \\
\text { à emergências }\end{array}$ & & & & & \\
\hline $\begin{array}{l}\text { Programas de capacitação, } \\
\text { treinamento e educação }\end{array}$ & & & & & \\
\hline
\end{tabular}

Quadro 4 - Pontos principais analisados

Os resultados apresentados ao longo dos anos que se sucederam ao processo de adequação e adoção de práticas sutentáveis, segundo o entrevistado, mostram um quadro evolutivo significativo. Os ganhos em eficiência produtiva decorrentes das medidas adotadas para tratamento e disposição de resíduos líquidos, sólidos e gasosos, bem como a preocupação com o consumo de água e energia elétrica, foram significativos pois, o uso 
racional destes elementos resulta numa redução acentuada de parte dos custos produtivos.

Observou-se que a preocupação com os indicadores associados ao desempenho ambiental é constante, com o estabelecimento de metas, como o objetivo de se obter melhoria contínua nos aspectos analisados

Tendo em vista os importantes ganhos em eficiência operacional, as práticas de gestão ambiental adotadas tornam-se cada vez mais atrativas em tanto termos financeiros quanto em melhoria na imagem institucional.

A perspectiva ambiental adotada pela empresa apresentou um quadro de gradativa evolução, à medida que os resultados apurados mostravam-se satisfatórios.

Atualmente, os projetos ambientais da empresa tem total apoio da alta administração, e os resultados dos programas sócio-ambientais desenvolvidos pela empresa são divulgados à sociedade, como uma forma de diferenciação do comportamento organizacional perante os aspectos relativos ao meio ambiente. A estratégia corporativa está totalmente voltada aos aspectos relacionados ao desenvolvimento sustentável.

Com esta apresentação das medidas adotadas, a instituição vem conseguindo obter uma imagem sólida e responsável, resultando em um diferencial competitivo. A tentativa de atrair consumidores engajados com 0 meio ambiente mostra-se válida, uma vez que a entrada de concorrentes estrangeiros, que não possuem certificação ambiental, torna-se uma ameaça competitiva pelo preço mais acessível oferecido. Um exemplo disto foi uma análise feita pela empresa $X$ de alguns produtos concorrentes: esses possuíam metais pesados em sua composição, danosos à saúde dos usuários.

\subsection{Análise das informações}

De acordo com as informações e dados obtidos durante a realização das entrevistas e das visitas técnicas, a empresa possui um posicionamento diferenciado perante as questões relativas ao gerenciamento dos impactos ambientais que suas atividades produtivas possuem. 
A sistematização dos procedimentos de gestão ambiental é relativamente recente, bem como a adoção e o estabelecimento de um SGA próprio e adequado às normas ISO 14.001 .

O princípio das ações neste âmbito de análise direcionou-se meramente para o cumprimento dos dispositivos legais vigentes. À medida que os resultados apresentados davam sinais de melhorias de eficiência operacional, a organização passa a ter maior motivação, ocasionando melhor desempenho ambiental.

Além de se resguardar das pesadas tarifações previstas na legislação, a empresa $X$ passa a visualizar oportunidades de ganhos em eficiência, através do uso racional dos recursos produtivos. Tais ganhos resultam em significativas e positivas mudanças na estrutura de custos para a empresa, motivando investimentos em tecnologia e inovações ambientais.

Desta forma, a instituição apresenta ao longo do tempo, o que pode-se denominar processo transitório no tratamento das questões referentes ao meio ambiente. Num primeiro instante, as motivações eram as multas $e$ as adequações previstas no arcabouço legal, ou seja, mera reação aos dispositivos jurídicos que poderiam acarretar impactos significativos nos resultados financeiros.

Posteriormente, a empresa passa a enxergar os dispositivos voltados à adequação ambiental como um diferencial competitivo, através das supracitadas melhorias em eficiência operacional. Com isso, passa-se ao processo de estabelecimento, adequação e certificação, bem como o uso de instrumentos de monitoramento do desempenho ambiental.

O objetivo de melhorar continuamente os indicadores de desempenho ambiental das atividades da empresa, a coloca numa rota pró-ativa e não mais uma mera reação.

Chega-se, então, à observação de que a empresa tem nos direcionadores econômicos e financeiros os principais indutores de suas atividades voltadas ao gerenciamento dos impactos ambientais.

$\mathrm{Na}$ etapa "reativa" a empresa adequava-se aos quesitos legais para que suas atividades produtivas não fossem afetadas por possíveis danos causados 
ao meio. Com a possibilidade de amealhar ganhos através da melhoria da eficiência operacional, a organização passa a visualizar os benefícios decorrentes das medidas em prol de um crescimento na performance ambiental. 


\section{Considerações Finais}

Tendo em vista a proposta de investigação do presente trabalho, no qual procurou-se analisar as motivações e as formas de internalização da variável ambiental pela organização escolhida, alguns pontos para discussão podem ser levantados.

Os principais direcionadores para a adoção de práticas voltadas ao gerenciamento ambiental foram de cunho econômico-financeiro. Num primeiro momento as multas previstas na legislação pertinente levavam à consideração de que seria mais custoso poluir do que adequar-se às normas ambientais. Observou-se, desta forma, o início de um processo de adequação, momento esse que torna-se o ponto de partida para uma abordagem sistemática voltada à variável ambiental.

Com a incorporação de práticas sustentáveis, mesmo que induzidas pela adequação jurídica, a organização passa a visualizar oportunidades de se obter retornos financeiros através dos benefícios gerados com possíveis ganhos em eficiência operacional, que, por sua vez, culminam em redução de custos. Esta perspectiva, juntamente com a noção de exaustão dos recursos naturais, que acarretam o aumento do preço desses mesmos recursos, leva a uma nova discussão: a poluição torna-se, para a empresa, um indicador de ineficiência sendo, assim, mais custosa.

Para reverter este quadro de ineficiência, a instituição passa a investir no desenvolvimento de técnicas destinadas à melhoria no aproveitamento dos recursos produtivos. Este fato pode ser comprovado através dos esforços realizados no tratamento e redução dos resíduos sólidos, líquidos e gasosos. Outra forma de maximizar o desempenho ambiental está relacionada à utilização da água e da energia elétrica, através de metas de redução de consumo das mesmas, bem como técnicas de tratamento da água. 
Além disso, com a adoção de uma postura favorável à preservação do meio ambiente, viabiliza-se um meio de diferenciar-se competitivamente. Este diferencial apresenta-se em três espectros principais: mudança significativa na estrutura de custos vigentes; melhoria da imagem institucional através da divulgação de uma postura sustentável e a diferenciação dos bens e serviços produzidos.

Desta forma, observou-se a sistematização dos procedimentos voltados à sustentabilidade das operações da empresa através do estabelecimento de um SGA, seguido das diversas certificações apropriadas, como ISO $14.001 \mathrm{e}$ FSC.

O estudo do comportamento da empresa $\mathrm{X}$ em questão, empresa essa que se apresenta com uma postura diferenciada frente às questões ambientais, serve como base para se compreender a visão sob a qual a inserção das organizações no meio ambiente deve ser discutida. Muitas questões têm sido contornadas pela tecnologia, porém os problemas relacionados à degradação ambiental estão distantes de um ponto final.

A partir dos aspectos analisados, a hipótese levantada inicialmente pelo presente estudo foi corroborada, uma vez que defendia-se que as empresas focariam os aspectos econômicos-financeiros no processo de incorporação dos preceitos voltados à gestão ambiental. Conforme discutido anteriormente, apesar da organização estudada se apresentar de forma plenamente satisfatória quanto à sua performance ambiental, seu objetivo primordial mostrou-se ser a maximização de seus resultados financeiros. Este fato pode ser comprovado pelas formas de adequação ambiental que a empresa adotou ao longo do tempo.

Diante de toda a discussão abordada em relação ao desenvolvimento sustentável, nota-se que a internalização da variável ambiental tende a ocorrer de uma forma gradual, ou seja, não se consolida de forma automática. A organização, geralmente, tende a vivenciar dois processos fundamentais: adequação e conformidade ao aparato jurídico e códigos setoriais; conscientização e incorporação estratégica da variável ambiental. 
Por fim, compreende-se que o âmbito da discussão dos temas relacionados à preservação do meio ambiente está aberto para novas investigações e está longe de se chegar a uma conclusão definitiva sobre o assunto. Neste contexto, o presente trabalho, com seus respectivos resultados, pode servir como base para estudos futuros. 


\section{Referências}

ANDRADE, R. O. B.; TACHIZAWA, T.; CARVALHO, A. B. (2000). Gestão ambiental: enfoque estratégico aplicado ao desenvolvimento sustentável. São Paulo: Makron Books.

AYRES, R. U.; BERGH, C.J.M.; GOWDY, J. M. (1998). Viewpoint: weak versus strong sustainability. Tinbergen Institute Discussion Papers, 98-103/3.

BARBIERI, J. C. (2004). Gestão ambiental empresarial: conceitos, modelos e instrumentos. 1.ed. São Paulo: Saraiva.

BORGES, F.H.; TACHIBANA, W. K. (2005). A evolução da preocupação ambiental e seus reflexos no ambiente dos negócios: uma abordagem histórica. In: Encontro Nacional dos Estudantes de Engenharia de Produção, 2005, Porto Alegre. Anais... Porto Alegre, PUC-RS.

BORGES, F. H.; TACHIBANA, W. K.; OLIVEIRA, J. G. (2005). Evolução do ambientalismo e os impactos no ambiente dos negócios. In: VIII Encontro Nacional sobre Gestão Empresarial e Meio Ambiente, 2005, Rio de Janeiro. Anais... Rio de Janeiro, FGV.

CABEZA-GUTÉS, M. (1996). The concept of weak sustainability. Ecologica Economics, n. 17, p. 147-156.

CONSTANZA, R. et al. (1998). The value of the world's ecosystem services and natural capital. Ecological Economics, n. 25, p. 3-15.

DANE, F. C. (1990). Research Methods. Belmont - CA: Brooks/Cole.

DASGUPTA, P.; MÄLER, K. (1995). Poverty, institutions, anda the environmental resource-base. In. Behrman, J. e Srinivasan, T. N. Handbook Development Economics, v. 3, Elsevier Science. 
DENARDIN, V. F.; SULZBACH, M. T. (2001). Capital Natural na perspectiva da economia. Disponível em <http://www.anppas.org.br/gt/recursos_hidricos/Valdir\%20Frigo\%20Denardin.pdf> DONAIRE, D. (1994) - Considerações sobre a influência da variável ambiental na empresa. Revista de Administração de Empresas (RAE), São Paulo: FGV, v.34, n.2, p.68-77.

DONAIRE, D. (1999). Gestão ambiental na empresa. 2.ed. São Paulo: Atlas. ENCICLOPÉDIA BARSA. (2005). O Protocolo de Kyoto. In: Livro do Ano de 2005.

FREY, M. R.; CAMARGO, M. E. (2003) - Análise dos Indutores da Evolução da Consciência Ambiental. Revista Qualitas. Disponível em: <http://www.uepb.rpp.br/revista_qualitas/artigos/artigos_2003/consciênciaambi ental.pdf.>.Acesso em: 09 dez. 2004.

GIL, A. C. (1999). Metodologia e técnicas de pesquisa social. São Paulo: Atlas, 1999.

GODOY, A. P. (1995) - Pesquisa qualitativa - tipos fundamentais. Revista de Administração de Empresas, São Paulo, v.35, n.4, p.65-71, jul./ago.

HANSEN, D. R.; MOWEN, M. M. (2001). Gestão de custos. São Paulo: Pioneira.

HAWKEN, P.; LOVINS, A.; LOVINS, L. H. (1999) - Capitalismo Natural. 1. ed. São Paulo: Cultrix - Amana-Key.

HEDIGER, W. (1999). Reconciling weak and strong sustainability. International Journal of Social Economics, v. 26, n. 7, 8, 9, p. 1120-1143.

HOFFMAN, A. J. (1999) - Institutional evolution and change: environmentalism and the US chemical industry. Academy of Management Journal. Mississipi State, Academy of Management, v. 42, aug.

HOFFMAN, A.J. (2001) - From heresy to dogma: an institutional history of corporate environmentalism. Stanford, Stanford Business Books, 2001, Expanded Edition.

JABBOUR, C. J. C.; SANTOS, F. C. A. (2005). Similaridades dos estagios evolutivos da gestao ambiental na empresa. In: VIII Encontro Nacional sobre 
Gestão Empresarial e Meio Ambiente, 2005, Rio de Janeiro. Anais... Rio de Janeiro, FGV. (artigo a ser publicado)

JACOBI, P. (1999) - Meio Ambiente e Sustentabilidade. Revista de Desenvolvimento e Meio Ambiente, São Paulo. Disponível em <http://www.cepam.sp.gov.br>. Acessado em 19/02/2005.

JUNQUEIRA, E. R. (2002). Utilização de Indicadores Econômico-financeiros para Avaliação do Desempenho Ambiental das Organizações: um estudo exploratório. 136p. Dissertação (Mestrado) - Faculdade de Economia, Administração e Contabilidade, Universidade de São Paulo, São Paulo. 2002.

KINLAW, D. C. (1997). Empresa competitiva \& ecológica. São Paulo: Makron Books.

LUSTOSA, M. C. (2004) - Industrialização, Meio Ambiente, Inovação e Competitividade. In: MAY, P. H; LUSTOSA, M. C.; VINHA, V. Economia do Meio Ambiente. $1^{\underline{a}}$ Ed. Rio de Janeiro: Campus. Cap. 6, p. 155-172.

MAIMON, D. (1994). Eco-estratégia nas empresas brasileiras: realidade ou discurso? Revista de Administração de Empresas (RAE), São Paulo: FGV, v.34, n.4, p.119-130.

MAXWELL, J. W. (1996) - What to do when win-win won't work: environmental strategies for costly regulation. Business Horizonts, set-out, p. 1-4.

MAC DONALD, D. V. (1999). Applying the concept of natural capital critically to regional resource management. Ecological Economics, n. 29, p. 73-87.

MEADOWS, D. H.; MEADOWS, D.; RANDERS, J.; BEHRENS, W. W. (1972) Limites do Crescimento. 1.ed. São Paulo: Perspectiva.

MEBRATU, D. (1998) - Sustainability and Sustainable Development: Historical and Conceptual Review. Environmental Impact Assessment Review, v. 18, p. 493-520.

MORANDI, S.; GIL, I. C. (2000). Tecnologia e ambiente. São Paulo: Codipart.

OLIVEIRA, J. G.; BORGES, F. H.; JABBOUR, C, J. C. (2005). O impacto competitivo da estratégia ambiental: uma abordagem teórica. In: Simpósio 
Internacional de Gestão Ambiental e Saúde, 2005, São Paulo. Anais... São Paulo, Senac. (a ser publicado)

PALMER, K.; OATES, W. E.; PORTNEY, P. R. (1995) - Tightening environmental standards: the benefit-cost or the no-cost paradigm? Journal of Economic Perspectives, v. 9, n. 4 (outono), p. 119-132.

PEARCE, D.; ATKINSON, G. (1998). The concept of sustainable development: an evaluation of its usefulness ten years after Brundtland. CSERGE GEC Working Paper 98-02, CSERGE, UEA, Norwich and UCL, London.

PORTER, M. E. (1992). Vantagem Competitiva: criando e sustentando um desempenho superior. 7. ed. Rio de Janeiro: Campus, 1992.

PORTER, M. E.; LINDE, C. (1995). Toward a new concetption of the Environment-Competitiveness Relationship. Journal of Economic Perspectives, v.9. n.4. (outono)

. (1999). Verde e Competitivo. In: PORTER, M. E. Competição. 1aㅡ Ed. Rio de Janeiro: Campus. Cap. 10, p. 371-397.

REDAÇÃO TERRA. (2005) - Protocolo de Kyoto entra em vigor após sete anos. Terra Notícias, São Paulo. Disponível em: $<$ http://noticias.terra.com.br/ciencia/interna/0,,Ol472859-El299,00.html>. Acessado em 16 fev. 2005.

REINHARDT, F. (1999) - Market failure and the environmental policies of firms. Journal of Industrial Ecology, Massachussets Institute of Technology and Yale University, v.3, n.1, p. 9-20.

REIS, M. J. L. (1997). ISO 14.000: gerenciamento ambiental, um novo desafio para a sua competitividade. Ed. Qualymark.

RENNINGS, K.; WIGGERING, H. (1997). Steps towards indicators of sustainable development: economic and ecological concepts. Ecologial Economics, n. 20, p. 25-36.

ROHRICH, S. S.; CUNHA, J. C. (2004) - A proposição de uma taxonomia para a análise da gestão ambiental no Brasil. Revista de Administração Contemporânea (RAC), Curitiba: Anpad, v.8, n.4, p.86-95, 2004. 
ROMEIRO, A. R. (2004). Economia ou Economia política da sustentabilidade. In: MAY, P. H; LUSTOSA, M. C.; VINHA, V. Economia do Meio Ambiente. $1^{\underline{a}}$ Ed. Rio de Janeiro: Campus. Cap. 1, p. 1-32.

ROSEN, C.M. (2001) - Environmental strategy and competitive advantage: an introduction. California Management Review, v.43, n.3, p.9-20.

SANCHES, C. S. (2000) - Gestão Ambiental Proativa. Revista de Administração de Empresas, São Paulo, v.40, n.1, p. 76-87, jan-mar.

SHRIVASTAVA, P. (1995). Environmental technologies and competitive advantage. Strategic Management Journal, Chichester, v.16, special issue, p. 183-200, summer.

SOUZA, R. S. (2002) - Evolução e Condicionantes da Gestão Ambiental nas Empresas. Revista de Administração da Universidade Federal de Santa Maria, Santa Maria - RS, v. 8, n. 6, p. 1-22, nov-dez.

SPOSATI, A. (2002). Movimentos utópicos da contemporaneidade. In: Ambientalismo e participação na contemporaneidade. São Paulo: EDUC/FAPESP, p. 11-39.

TURNER, R.K. (1992). Speculations on weak and strong sustainability. CSERGE GEC Working Paper 92-26, CSERGE, UEA, Norwich and UCL, London.

TURNER, et al. (1994). Environmental economics: an elementary introduction. New York: Harvester Wheatsheaf, 328 p.

VALLE, C. E. (2000). Como se preparar para as normas ISO 14000: qualidade ambiental: o desafio de ser competitivo protegendo o meio ambiente. São Paulo: Pioneira.

VINHA, V. (2004). As empresas e o desenvolvimento sustentável: da ecoeficiência à responsabilidade social corporativa. In: MAY, P. H; LUSTOSA, M. C.; VINHA, V. Economia do Meio Ambiente. $1^{\text {a }}$ Ed. Rio de Janeiro: Campus. Cap. 7, p. 173-197.

YIN, R. K. (2001). Estudo de Caso: planejamento e métodos. Porto Alegre RS: Bookman, 2001. 
YOUNG, C. E. F.; LUSTOSA, M.C.J. (2001). Meio ambiente e competitividade na indústria brasileira. Revista de Economia Contemporânea, v.5, edição especial. Rio de Janeiro: IE/UFRJ, p. 231-259.

WALLEY, N; WHITEHEAD, B. (1994). It's not easy being grenn. Harvard Business Review. Boston, v.72, p. 37-50, mai-jun. 


\section{Anexo 1}

A seguir, será apresentado um roteiro desenvolvido para a realização das entrevistas agendadas, com o intuito de coletar os dados e informações pertinentes à pesquisa.

Após a gravação em arquivos de áudio, as entrevistas foram transcritas literalmente e, numa etapa posterior, os principais pontos relevantes foram inseridos na apresentação feita no capítulo 5.

\section{Parte 1 - Questões que abordam o tratamento das questões ambientais pela organização:}

A - quais foram os fatores motivadores que induziram a empresa a realizar procedimentos sistemáticos com relação ao gerenciamento do meio ambiente?

a.1 - apresente uma breve revisão histórica dos fatos relacionados B - Como se encontram, atualmente, os procedimentos voltados à gestão ambiental na empresa?

b.1 - Dispõe de um SGA plenamente estabelecido?

b.2 - Dispõe de Política Ambiental e seus meios de divulgação ao longo da organização?

b.3 - Dispõe de objetivos de metas ambientais?

b.4 - Dispõe de processos de identificação dos aspectos ambientais relativos às operações da empresa?

C - quais são as certificações existentes? Atendem a algum requisito de mercado?

\section{Parte 2 - Orientações Específicas}

A - Existe um departamento que cuide fundamentalmente da Gestão Ambiental?

a.1 - as atribuições deste departamento 
B - Os procedimentos, voltados à sustentabilidade das operações da empresa, são plenamente apoiados pela alta adminsitraçao?

C - Há objetivos estratégicos orientados para a Gestão Ambiental?

D - Os impactos operacionais decorrentes do processo de adoção de práticas sustentáveis

E - Os efeitos gerados pela divulgação do projetos ambientais realizados pela empresa. 